Cultura y

coaliciones de

poder y dinero

en las nuevas

gestiones

urbamas

otilia Arantes 


\section{Cultura y coaliciones de poder y dinero en las nuevas gestiones urbanas}


Categorías: Filosofía; Política; Estética; Arquitectura y Ciudades; Artes plásticas; Crítica de cultura y trayectorias. Cada categoría adopta un color específico en la portada del libro electrónico.

\section{Subcolecciones:}

Libros electrónicos: libros, capítulos, prefacios, artículos y entrevistas (en formatos PDF, EPUB y MOBI / Kindle) - con obras en portugués, inglés, español, italiano y francés.

Documentos: artículos de periódicos, fotografías y documentos históricos (en formato PDF y JPEG)

Medios: Vídeos o audios de conferencias, clases y debates (en formatos MP3 y MP4) asociados a un canal de YouTube de la colección.

Coordinación editorial: Pedro Fiori Arantes

Proyecto gráfico: Paula Astiz

\section{Datos Internacionales de Catalogación en Publicación (CIP)}

\section{Arantes, Otília Beatriz Fiori, 1940-}

Cultura y coaliciones de poder y dinero em las nuevas gestiones

urbanas [livro eletrônico] / Otília Beatriz Fiori Arantes ; [tradução Ada Solari e Adrián Gorelik]. -- São Paulo : [s.n], 2021.

ePUB. - (Colección sentimento da dialética / ccoordinación Pedro Fiori Arantes)

\section{ISBN 978-65-00-34962-7}

1. Planejamento urbano. 2. Cidades e vilas. 3. Capitalismo. 4 . Sociologia urbana. 5. Espaços públicos. I. Arantes, Pedro Fiori,

1974-. II. Título. III. Série.

CDD 307.76

Elaborado por Cristiane de Melo Shirayama - CRB 8/7610

DOI: https://doi.org/10.34024/9786500349627

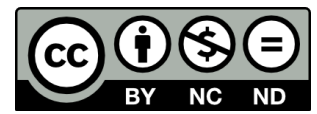

Esta obra tiene licencia Creative Commons internacional 4.0

http://creativecommons.org/licenses/by-nc-nd/4.0/

Publicado originalmente en:

"Los espacios..." es un resumen de la comunicación presentada en el XIX Coloquio Internacional de Historia del Arte de la Universidad Nacional Autónoma de México, 1995 "Pasen y veán..." fue publicado en la revista Punto de Vista no 66, Buenos Aires, abril de 2000, pp.16-19, traducción de Adrián Gorelik.

"Cultura y colaiciones..." fue publicado en la revista Block, $n^{\circ} 5$, Buenos Aires, UTDT, 2000, traducción de Ada Solari.

\section{Sentimento da Dialética}

UN ENCUENTRO CON LA OBRA DE OTÍLIA Y PAULO ARANTES

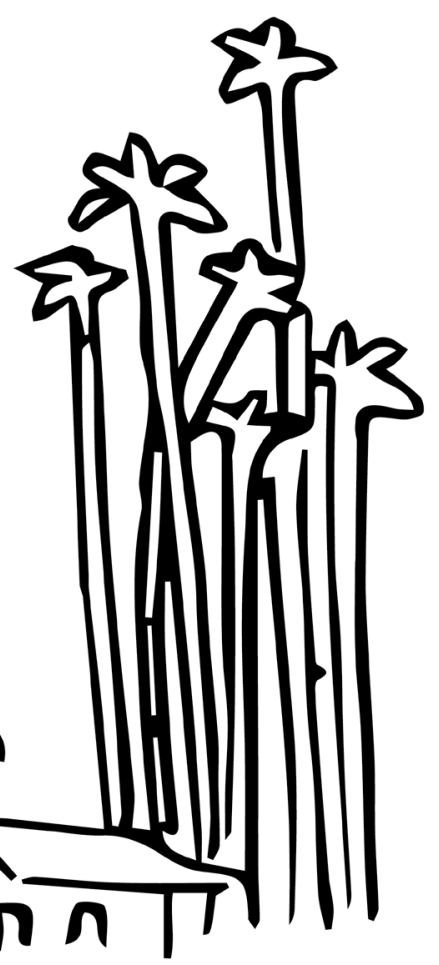




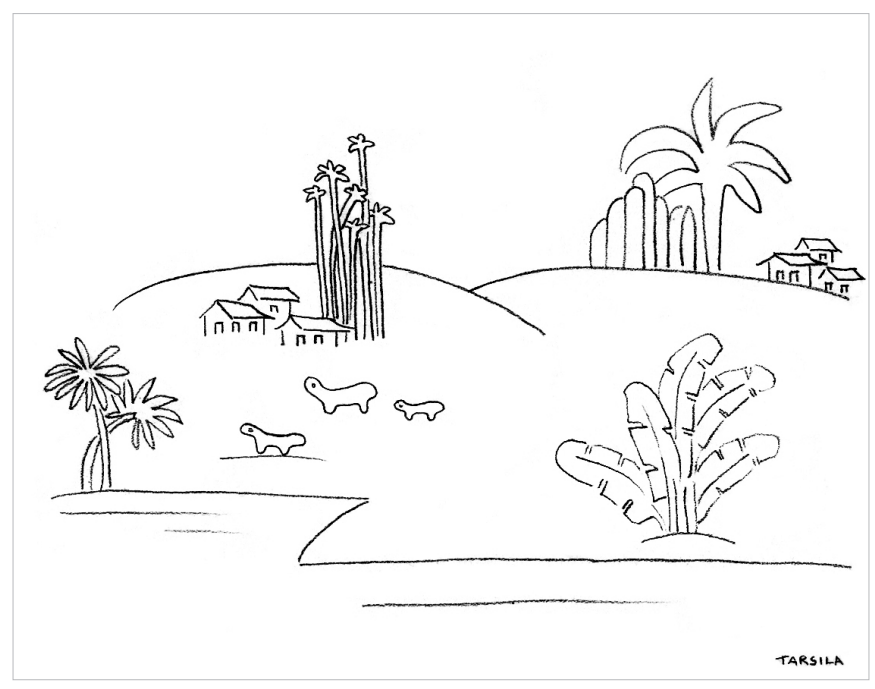

Tarsila do Amaral. Paisaje antropofágico - I, 1929 c - lápiz sobre papel, $18,0 \times 22,9 \mathrm{~cm}$. Colección Mário de Andrade.

Colección de Artes Visuales del Instituto de Estudos Brasileiros USP. Reproducción amablemente proporcionada por la familia y el IEB USP.

El nuevo tiempo del mundo exige a los intelectuales responsabilidades que les son intrínsecas: hacer que el poder de las ideas forme parte del movimiento de comprensión y transformación del mundo. Los filósofos Otília Beatriz Fiori Arantes y Paulo Eduardo Arantes llevan más de 50 años desarrollando juntos la tarea de la crítica como intelectuales públicos activos, moviéndose entre diferentes áreas de las humanidades y la cultura, en diferentes públicos y espacios de formación. La colección Sentimento da Dialética recopila y edita en libros digitales gratuitos su producción intelectual, es un lugar de encuentro de la obra de Otília y Paulo Arantes y reafirma el sentido colectivo de la misma. Es un encuentro de su obra con un público cada vez más amplio, plural y popular, formado por estudiantes, nuevos intelectuales y activistas brasileños. Es también un encuentro de su obra con el movimiento contemporáneo en defensa del conocimiento libre y desmercantilizado, en la producción de lo común y de otro mundo posible. ctivistas brasileños. Es también un encuentro de su obra con el movimiento contemporáneo en defensa del conocimiento libre y desmercantilizado, en la producción de lo común y de otro mundo posible. 
$11 \quad$ Los espacios públicos en las nuevas estrategias urbanas

$31 \quad$ Pasen y veán... Imagen y city-marketing en las nuevas estrategias urbanas

41 Cultura y coaliciones de poder y dinero en las nuevas gestiones urbanas 

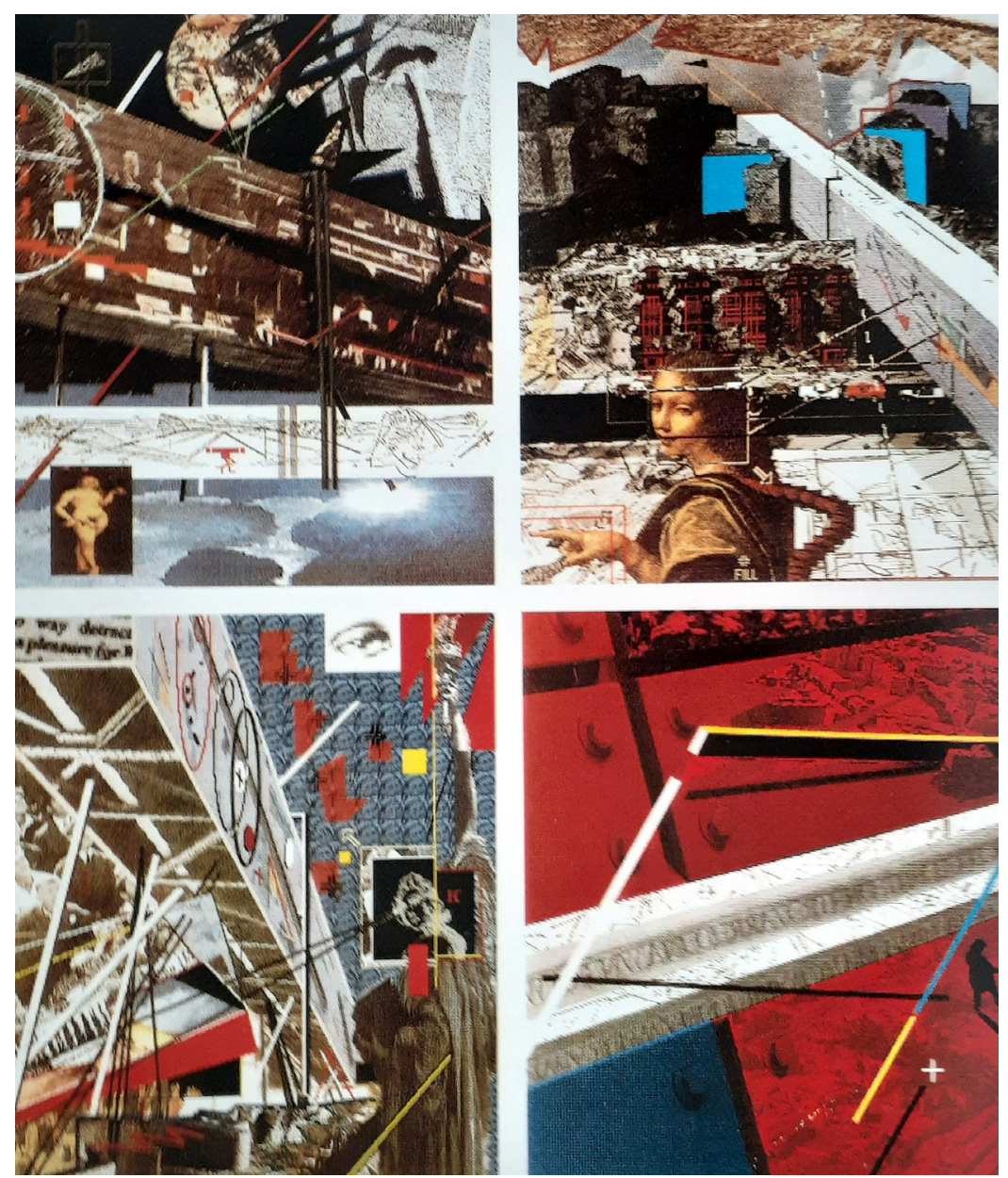

Libeskind, Concurso para el Centro de Berlin, 1987-88

\section{Los espacios públicos en las nuevas estrategias urbanas*}

Como pudimos testimoniar en este seminario, uno de los grandes temas del debate cultural actual es sin duda el cambio, para muchos radical, en la experiencia del espacio - sea como consecuencia de la velocidad de los medios de transporte, o de los todavía más veloces recursos electrónicos-, que obliga a los individuos a alterar su percepción espacio-temporal y, en última instancia, su propia inserción en la realidad. Evidentemente, esta transformación hizo caducar cualquier expectativa que se pudiese alimentar en el sentido de recomponer una vida pública a partir de una operación tangible de circunscripción de los espacios urbanos como lugar cargado de sentido, algo capaz de propiciar el reencuentro con hechos colectivos "memorables"; circunscripción que permitiría reactivar una sociabilidad perdida a lo largo de estos dos últimos siglos de modernización de las ciudades. Modernización cuyo hielo burgués ganó sin embargo nuevo y definitivo impulso de la urbanística moderna - justamente por sus compromisos con la homogeneización capitalista, especialmente en su fase taylorista y fordista. En realidad, ese clima de opinión se remonta a las primeras secesiones del

* Resumen de la comunicación presentada en el XIX Coloquio Internacional de Historia del Arte de la Universidad Nacional Autónoma de México, Instituto de Investigaciones Estéticas, 1995. La íntegra en portugués ha sido publicado en los anales, pp. 671-684. 
Movimiento Moderno en la posguerra, pero recién en las dos últimas décadas tomó el aspecto de lugar común ideológico - punto de encuentro, bien tamizado, entre viejos argumentos conservadores y otros tantos cosechados en la moda neoiluminista más reciente-, siendo menos una respuesta que una caja de resonancia de las sucesivas metamorfosis de la esfera pública en el capitalismo avanzado. Sin embargo, como hace tiempo que la ideología pasó del discurso para las propias cosas (que son propaganda de sí mismas), hoy en día ni siquiera se pueden alimentar esas ilusiones compensadoras.

Así, no sólo la inviabilidad de tal proyecto se hace evidente sino que también los desdoblamientos inesperados de aquellas ideas acaban convirtiéndose en lo que parece su exacto contrario: la causa sorprendente de un urbanismo anárquico de apología de la ciudad caótica, plural, fragmentada, soft etc. Cabe preguntarse si no se substituyó la ideología del plan del Movimiento Moderno por otra, la ideología de la diversidad, de las identidades locales, donde los conflictos seriam escamoteados por una especie de estetización de lo heterogéneo, recubierto por la transformación, en escenarios comandados por la lógica de la fascinación, de la superficie desencantada (en la acepción que Max Weber le daba a esta dimensión clave del mundo moderno) de nuestras ciudades; escenarios imantados por una sociabilidad que hace mucho tiempo dejó de existir justamente en virtud de ese trazo esterilizante de la modernización. O sea que, el lugar, inviable por las propias condiciones objetivas, materiales, fue convirtiéndose, de a poco, en su opuesto, el no-lugar de los espacios_virtuales de una vida pública definitivamente transformada en un repertorio de representaciones simbólicas.
Cuando hace más de veinte años, el dudoso Robert Venturi proponía una arquitectura de la comunicación y no del espacio ${ }^{1}$ - como siempre fue definida-, criticando la obsesión de sus colegas por la adopción de soluciones urbanísticas tradicionales, como las plazas con sus "genius loci”, y defendía la generalización del modelo de las calles comerciales llenas de anuncios luminosos, o sea, una arquitectura impura, simbólica, de comunicación vigorosa e inmediata, que recurriese a símbolos y señalizaciones de fácil decodificación - al contrario de la arquitectura Moderna, expresiva por la forma-, él ya asumía de modo muy explícito la transformación de la arquitectura en "arte" (?) de masas: forma-mercadería en su etapa apoteótica de Forma-Publicitaria. Al mismo tiempo, esta nueva versión de la vida urbana era vista como la contrapartida de un reflujo del individuo hacia el interior doméstico, delante de su televisión, único medio de contacto con el mundo externo, al que hay que añadir, evidentemente, el automóvil - especie de cápsula sobre ruedas dirigida por un computador, mientras el paisaje alrededor parece sucederse como las imágenes en un monitor de T.V. Así, tenemos por un lado la casa y por otro las strip - de las calles comerciales a las grandes arterias recorridas a toda velocidad, con sus out-doors y placas o símbolos indicativos, en general, de lugares y productos para consumir. Entre el micro espacio de la sala y el hiperespacio de las grandes autopistas, la diferencia sería sólo de escala; en

1. Cf. Robert Venturi y Denise Scott Brown, Aprendiendo con Las Vegas, el simbolismo olvidado de la forma arquitectonica, Barcelona: Gustavo Gili, 1978. 
ninguno de los casos se trataría exactamente de lugares de estar, sino, más bien, de circular. Circulación general de imágenes, con la levedad de la forma-mercadería, que abandonó definitivamente el nexo con el mundo concreto de la producción. Proliferación de signos autorreferentes, justamente el tan decantado mundo del simulacro, en la versión de sus ideólogos.

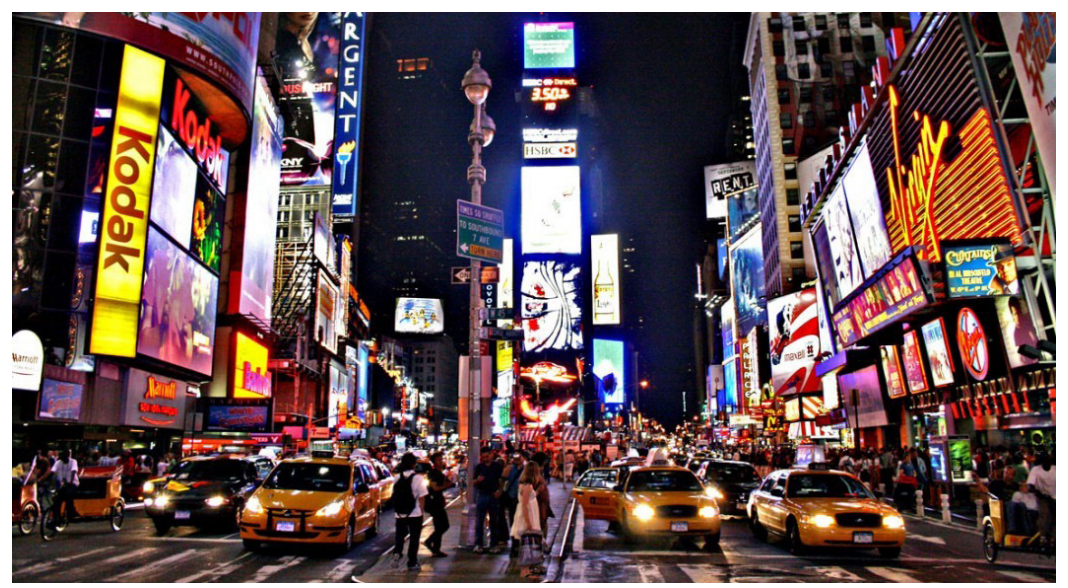

Times Square, NY, a la noche

Concretamente: el ejemplo del automóvil en movimiento - por cuyas ventanas desfila el paisaje como en una tela de video, en el que el modelo de la experiencia alucinante es la producción industrial del simulacro-, también puede leerse teniendo en cuenta el carácter determinante de lo que se ve desde el coche. "Si usted va a Times Square, en Manhattan, o viaja por cualquiera de las carreteras americanas", afirma el crítico Peter Fuller, "se depara con un flujo de imágenes que parecen más reales que la propia realidad”. "Tiene la impresión de un mundo físico en el que las cosas fueron desmaterializadas o re- ducidas a superficies". ${ }^{2}$ Tal sensación (que Venturi destaca como fuente de una arquitectura adecuada a nuestros días) no se debe exclusivamente a la inflación pop de la publicidad. Como el propio Fuller subraya, en la metrópolis de hoy, es la vida la que nos arrastra para un mundo de superficies - o, como diría otro teórico de este estado de cosas actual, Baudrillard ${ }^{3}$ : es en la ciudad donde experimentamos el mundo como obscenidad (es decir, algo así como un close de una película pornográfica...). Así, continúa Fuller, el imperio de la "planura" en la pseudofiguración hiperrealista, o en el arte minimalista (y es a este último al que se refiere) es parte de una experiencia urbana más ancha en la que predomina una especie de omnipresencia de lo superficial (cuya matriz, por cierto, es la ciudad americana).

En esa época, afirmaciones como la de Venturi aparecían como una consagración, cuando menos cínica, de la sociedad de consumo, un poco a la manera de los artistas pop. De hecho, hoy sabemos que era el primer capítulo de una tendencia que acabó dominando la arquitectura y el discurso sobre ella, en la cual no sólo el espacio es obliterado por la velocidad de los medios de transporte, sino también por la instantaneidad de la difusión electrónica. Como dirá Virilio al término de ese proceso de mediatización e informatización: "gracias al material imperceptible del tubo catódico, las dimensiones del espacio se tornaron inseparables de su velocidad de transmisión. Unidad de espacio sin unidad de tiempo, la Ciudad desaparece en la heterogeneidad del régimen de temporali-

2. Apud Cristopher Lash, O mínimo Eu, São Paulo: Ed. Brasiliense, 1984, p. 155.

3. Les Stratégies Fatales, Paris: Grasset (Livre de Poche), 1983, pp.55-76. 
dad de las tecnologías avanzadas”. La Ciudad estaría en un proceso de desurbanización progresiva - ya se habló mucho de posarquitectura, posurbanismo o posurbanidad para designar esta nueva fase-, por la pérdida de su unidad espacio-temporal en nombre de un tiempo-espacio sintético y virtual. Condensación que habría tornado todo superficial; escenarios cada vez más "inmateriales", hasta el "espacio íntimo, la propia naturaleza domiciliar", reducido a centrales de teledistribución. ${ }^{4} \mathrm{O}$ incluso, en un registro muy diferente, según David Harvey y algunos teóricos regulacionistas, estaríamos viviendo una "compresión del tiempo-espacio", resultante de una nueva etapa del capitalismo, de aceleración del tiempo de giro de las mercaderías, su instantaneidad y descartabilidad; o sea, el carácter efímero de la ciudad flexible, fragmentaria, volátil, soft, correspondería a una economía posfordista —de acumulación también flexible-: la del capitalismo desorganizado y globalizado. ${ }^{5}$

En verdad, se trataría de un giro objetivo y no de una mera alteración de modelos ideológicos. Cambio profundo, responsable por la nueva lengua franca que es el discurso de la ciudad - incluyendo hechos, porque se trata de actos de habla performativos, pues la ciudad también pasó a ser aquello que se dice de ella. Aquí está lo decisivo: a favor o en contra, todos hablan la misma lengua, teóricos y gestores urbanos en general. A continuación, me gustaría recordarles cómo se dio no sólo esa transformación brusca sino, además, esa nivelación terminológica y

4. Virilio, "A cidade Superexposta” y "A Arquitetura Improvável”, in O espaço crítico, Rio de Janeiro: Ed.34, 1932.

5.David Harvey, Condição Pós-Moderna, São Paulo: ed. Loyola, 1992, especialmente capítulos 4,18 y 25. conceptual, indiferente a las mejores intenciones críticas.

Por ejemplo, en la Trienal de Milán de 1988 - La Imagen de la Ciudad-, uno de sus organizadores, Georges Teyssot, caracterizaba "La Metrópolis puesta en representación" como una "mise en scène de irracionalidades proliferantes" - no más mapas, gráficos, ejes, jerarquías, sino desterritorialización, desimbolización, "errancia", delirio esquizoide (citando a Ballard, pero, seguramente, teniendo también en mente a Lacan, Deleuze, Guattari etc). ${ }^{6}$ Clara demostración de la a mplia hegemonía de la Ideología Francesa, presente también en el raciocinio urbano y en el debate arquitectónico actual. Todo se transforma en cualidades movedizas o atributos fluctuantes, derogaciones, desconstrucciones, derivas. Shinohara dirá: el CAOS se transformó en un concepto clave, los objetos aleatorios del paisaje de Toquio preanunciaban la ciudad electrónica en la que se está transformando. ${ }^{7} \mathrm{El}$ mismo modelo o antimodelo se reproduce a escala internacional. Así, cada vez más teóricos, arquitectos o gestores urbanos abandonan sus pretensiones no sólo de cualquier planificación global de la ciudad, sino también de todo tipo de organización, aunque sea parcial, que la torne un conjunto de espacios mínimamente ordenados y que puedan transformarse en formas definidas y estables, como para proveer una imagen coherente a ser visualizada o representada por sus habitantes como un tejido cohesivo, con algún poder y equilibrio de la organización visual o semántica, configurando (en la terminología que dominó el pensamiento

6. "La métropole mise en représentation", in Urbanisme: la ville entre image et projet, Paris: Cahiers du CCI n.5, 1988, pp.10-18.

7. “Villes, Chaos, Activités", in ibid., pp. 43-51. 
urbano hasta hace poco tiempo) un lugar. Al contrario, la nueva jerga se compone de términos que intentan designar la no urbanidad de la ciudad, su atopia: no-territorio, lugar virtual, no-lugar etc. Transbordando sus límites, la ciudad se va convirtiendo en una gran red intercomunicable y, aparentemente, intercambiable. Volviendo a Virilio: éste llega a decretar la desaparición no sólo del espacio/ lugar, sino también del calendario de una memoria colectiva. Los muros de la ciudad habrían sido derrumbados al son de la media (de los medios de comunicación).

Como decía, esta nueva retórica no deja de tener un fondo de verdad, algo cambió en esa nueva fase de la sociedad de masa: la apoteosis publicitaria de la forma-mercadería, finalmente universalizada, redundó en la reducción de la arquitectura de la ciudad a una simulación imagética, compuesta de signos polivalentes que contienen en sí mismos informaciones contradictorias, superposiciones, contaminaciones etc, destinadas a un mercado que se alimenta cada vez más de la diferencia y de lo obsoleto - más precisamente, que resultan de una administración soft de la cultura que ya no tiene como objetivo domesticar las diferencias, sino reproducir su inconciliabilidad. ${ }^{8}$ Ésa es, tal vez, la cuestión central a ser decifrada en el nuevo discurso sobre la ciudad y enfrentada por las nuevas estrategias urbanas.

8. Cf. tambien sobre el tema, Massimo Ilardi (org.) La cittá senza Luoghi, Gênova: ed. Costa \& Nola, 1991.

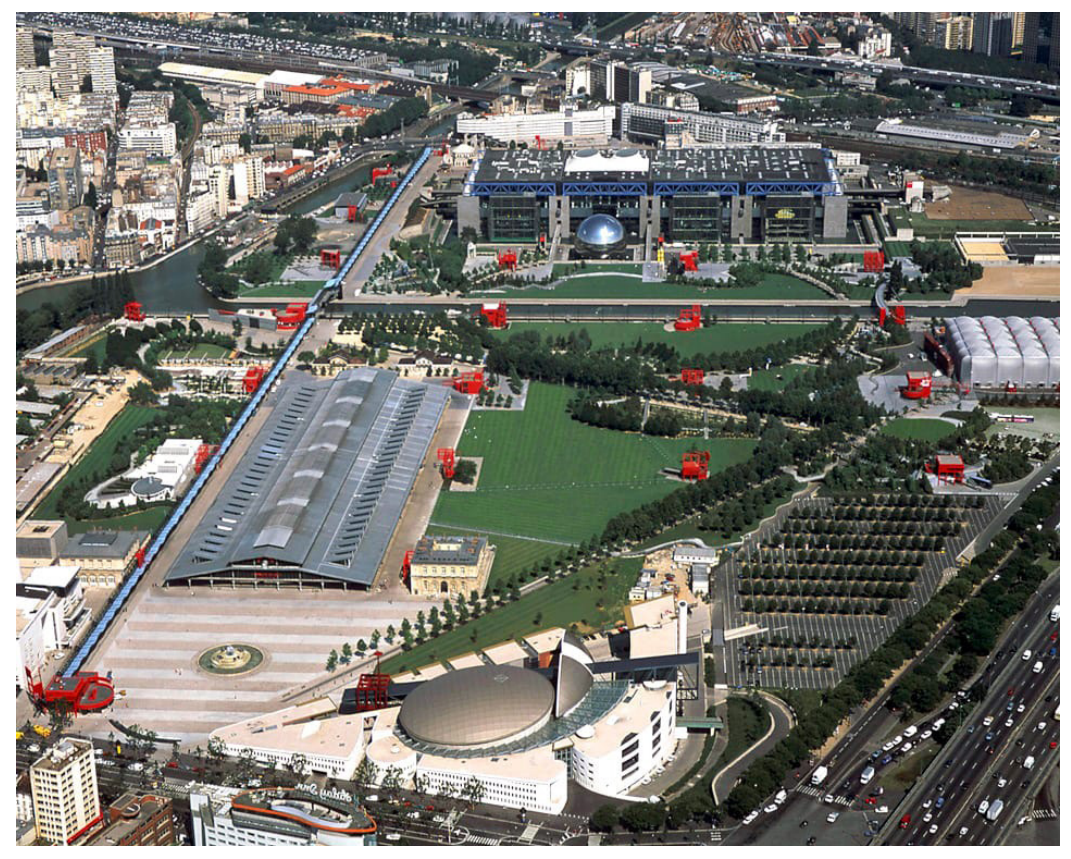

Vista aerea del Parque de la Vilette, Paris, años 80-90

$*$

Para evitar una recapitulación muy extensa y cuyo resumen enuncié en la introducción, retomo apenas en breves trazos el proceso que, después del colapso de la idea de planificación global de la ciudad, llevó a arquitectos y urbanistas de la casi obsesión por restaurar una urbanidad perdida - la ciudad como lugar público- a la apología del caos, de la ciudad laberíntica, del "errancia", del (des) orden etc.

En contraste con posiciones como la de Venturi, especialmente desde mediados de los años 60 hasta el final de los 80 , buena parte de los arquitectos y urbanistas se entregó - con la intención de devolverle la ciudad moderna a la colectividad que había sido expropiada durante el pro- 
ceso de constitución de las grandes aglomeraciones urbanas contemporáneas-, a una verdadera obsesión por el lugar público, aparentemente el antídoto más indicado para la patología de la ciudad funcional. ${ }^{9}$ Pasaron entonces a crear —o, simplemente, a preservar - hechos urbanos, lugares destinados en principio a reactivar formas de vida social, focos en condiciones de aglutinar alrededor de un espacio que se presentase como res publica, un sin número de objetos arquitectónicos desconexos (sólo para colocar un ejemplo, tal vez el más importante: el grupo italiano que pretendía ser neorracionalista y neorrealista, Tendenza, con ramificaciones en toda Europa). Vida pública pensada, mientras tanto, la mayoría de las veces, en términos de reactivación de ideales comunitarios - lo que en realidad, en lugar de una reminiscencia del mundo tradicional, erigida en instancia crítica de los traumas de la modernización, no pasa de una atrofia de la hora presente: los nuevos ideales de comunidad expresan una fobia ultramoderna, el temor de la vida civil activa, contaminada a su vez por el virus de la "intimidad", (como fue ampliamente expuesto por algunos críticos de la cultura, como por ejemplo, Richard Sennet o Lash). Sin embargo, estas estrategias aparentemente opuestas acabarán por coincidir: Venturi no dejaba de ser un contextual a su manera y las estrategias del lugar terminaron mostrándose como otras tantas modalidades de refuerzo de la fragmentación urbana, de sublimación de la ausencia de vida pública en una política de neighbourhood. En el caso del arquitecto americano, la lección de modestia y realismo también

9. Para una reconstución mas detallada, ver "A ideologia do Lugar Público na Arquitetura Contemporânea (um roteiro)", in Otília Arantes, O Lugar da Arquitetura depois dos Modernos, EDUSP, 1995 ( $2^{\text {a }}$ ed.), pp. 95 a 155. [Reproducido en este site en Cultura, poder e dinheiro nas novas gestões urbanas.] viene de las calles; sin embargo, no se aprende la misma cosa en Las Vegas y Boloña (el gran ejemplo de arquitectura contextual y de política patrimonial de los disidentes europeos): en un caso, es el strip, la calle comercial americana, que le impone a la arquitectura la ley del pop; en el otro, las cuestiones tipológicas y morfológicas brotan de la consciencia polémica de appartenenza a un "lugar". La convergencia final de las dos visiones, que parecían partir de puntos de vista divergentes, es la prueba más cabal de lo que venía diciendo a propósito del campo de fuerzas materiales que comandan el actual discurso urbano, que a su vez también forma parte de su proceso de reproducción.

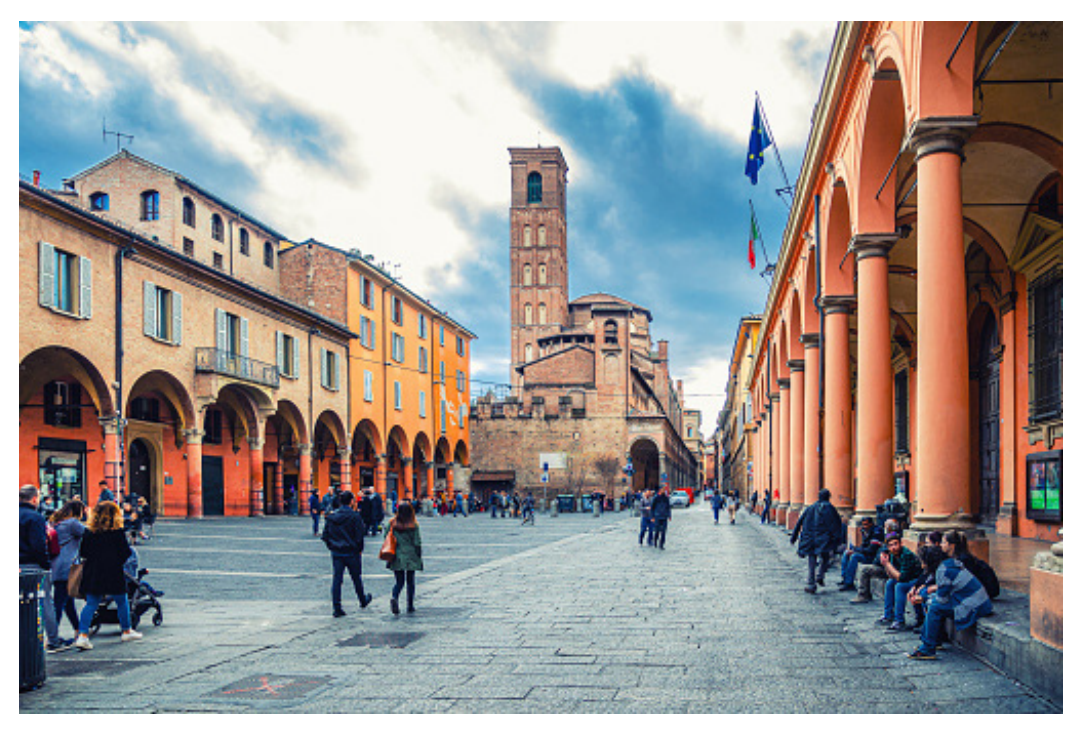

El centro Antiguo de Bologna, recuperado en los años 60 


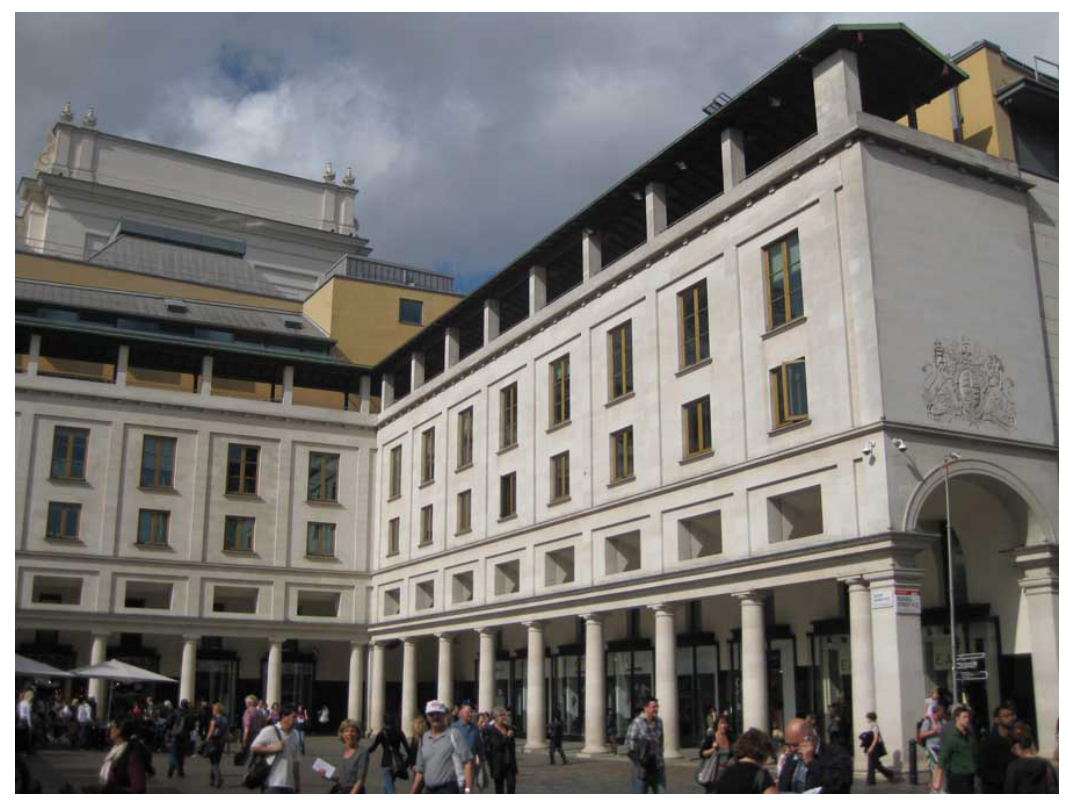

Plaza al lado de la Opera House, Covent Garden, London, Reforma comandada por el escritorio de Jeremy Dixon e Edward Jones, después del 1975

Al querer restituir la ciudad a su dimensión cívica, hay que tener en cuenta el hecho de que la decadencia del hombre público y el correspondiente ensanchamiento de la esfera privada - pero desfigurada como intimidad narcisista - están en el origen de la mayor parte de las patologías urbanas. Al comienzo del siglo, las filosofías de la Vida, de la Intuición etc, buscaron en lo inmediato el fundamento sobre el cual basar la reconstitución de la experiencia. Según observó cierta vez Adorno, prueba de que lo inmediato se perdió en la red sin comienzo ni fin de las mediaciones: cuanto más se alega la vida como principio, menos está presente en el origen buscado en vano. La ciudad moderna es la propia imagen de esa mediación sin tregua. En términos de nuestro problema: en la misma proporción en que se consolida la sociedad de masas, aumenta el dominio privado, pero entendido ahora como el dominio del falso inmediato. Lo que se ve es la creciente indiferenciación entre los espacios: el del ámbito doméstico y el exterior, igualmente sujetos a la temporalidad de la circulación de las imágenes, o sea, homogeneizados por el mundo del marketing.

En poco tiempo el desenlace de esa mutación se hará sentir, empezando en el plano de la fraseología de moda, pues fue el posestructuralismo el que se encargó de estilizar y justificar las prácticas autodenominadas dispersivas, descentradas etc - exacerbación de la individualidad como pérdida de la subjetividad (por eso, sociedad narcísica), muerte del Yo, debilitamiento de la voluntad y al mismo tiempo reflujo hacia el ámbito individual, comandado por una lógica de la intimidad, entre otros. No espanta que un fenómeno similar ocurra con la ciudad y sus transformaciones. ${ }^{10}$ Obviamente, no se trata de una aplicación, uniforme o no, de la teoría a la práctica, al contrario, aquélla seguramente apenas explicita lo que ocurre en el ámbito de la sociedad, o mejor dicho, el despedazamiento de ésta se traduce en la desconstrucción del discurso transformado en texto-, donde todas las relaciones son reversibles y las significaciones indescifrables. Al mismo tiempo, todo se transforma en texto, la escritura de la ciudad es de la misma magnitud que la del mundo prosaico o del arte. Todo se interpenetra. Intertextualidad generalizada, o sea, las identidades culturales comienzan a ser interpretadas en términos de transitividad o de nomadismo de las interculturalidades - los antiguos "propagandistas" de la identidad están prefiriendo hablar de transcul-

10. Sobre esto, ver el mio texto, "A cidade como não-lugar", in A.U., n58, fev/ mar 95, pp.83-85. 
turalismo, translocalismo, frontera (no como límite fijo, sino como el que puede ser transpuesto, desplazado, diferido etc - margen, edge), mestizaje, entre otros.

En gran parte, la ciudad fragmentaria es ésto: el resultado del llamado "nuevo orden mundial", justamente aquél del "capitalismo desorganizado". Al menos es ésta la tesis de David Harvey (y no sólo de él), mencionada antes: la configuración caótica de la ciudad sería apenas la cara más visible de este actual estado de cosas, tanto cuanto la inmediata estetización del sublimado astillamiento espacial. Flexibilidad, fluidez, multiplicidad, atopia... - directrices de un urbanismo que se cree sin modelos, plural, antiautoritario y todo lo demás, en verdad, apenas reforzando una situación que no es más que el resultado de la más siniestra segregación. Además, las nuevas tendencias estructurales de crisis de la regulación social y de desmonte de los Estados nacionales, va transformando los alegados valores locales en mercaderías a ser tanto consumidas como recicladas a la misma velocidad a la que se mueve el capital. En líneas generales, ése es el nudo de la renovación urbana en camino, tanto en los países ricos, cuanto, con más razón todavía, en los periféricos.

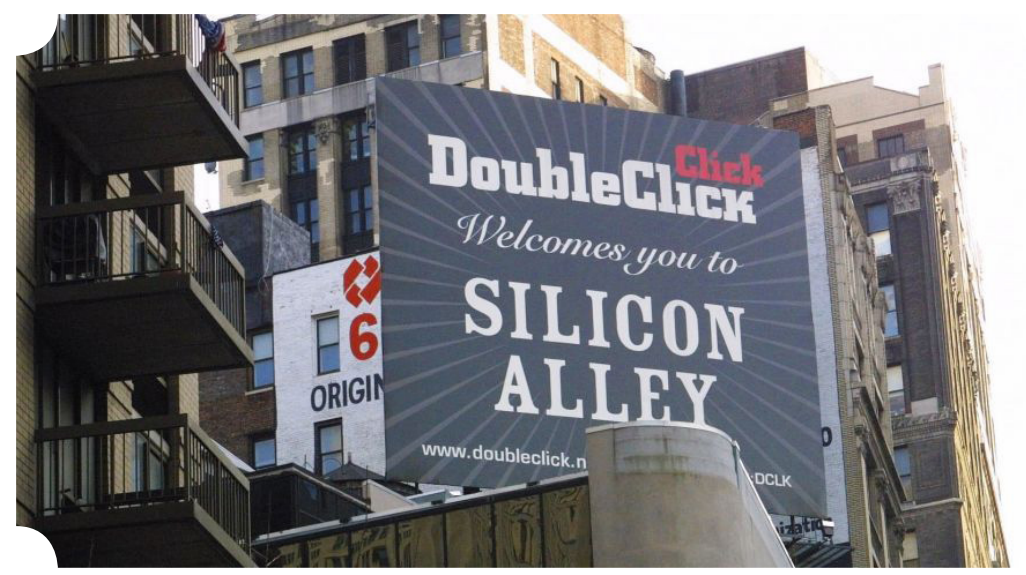

Silicon Aley, al sur de Manhattan, NY

$*$

Al mismo tiempo que las ciudades parecen volatilizarse en el espacio-tiempo sintético de las redes de comunicación -o sea, desaparecer en la pura virtualidad de las imágenes electrónicas-, nunca se cultivó tanto, tal vez por eso mismo, la apariencia (o transparencia, como diría Virilio) de las mismas. Nunca se reivindicó tanto la necesidad de "recalificación”, especialmente de las áreas más antiguas, sobre todo los centros urbanos - los movimientos de "salvación" de las ciudades proliferan por todas partes. Se van multiplicando espacios que, seguramente, no tienen más nada que ver con los lugares a los que nos referíamos hace poco; al contrario, son el opuesto exacto, aquello que Marc Augé llama no-lugares - sucedáneos de los lugares públicos: justamente los espacios que solamente se prestan a la circulación y al consumo; tendríamos que añadir los espacios verdes, las plazas etc, lo que otrora fue o se imaginó que serían, sino para la vida pública, por lo menos, para un mínimo de convivencia social. “Un mundo así prometido a la individualidad solitaria, a 
lo pasajero, a lo provisorio y a lo efímero". O todavía, el horizonte de todo viaje - espacio como suma de lugares (no del lugar) apenas entrevistos, visiones instantáneas, parciales, en que de hecho lo que le importa al individuo es él mismo como espectador, mucho más que el espectáculo. ${ }^{11}$ Siempre sobredimensionados (los hiperespacios de los que hablaba Fredric Jameson) ${ }^{12}$ e incapaces de propiciar cualquier tipo de intercambio social: no son más ni siquiera escenarios de una sociabilidad inexistente, como en el tiempo de la arquitectura del lugar; son apenas extensiones para recorrer o, meramente, ser reproducidas por la máquina fotográfica o por el ojo electrónico, ya que no se prestan más a ningún tipo de uso o cuyo uso obedece a reglas y horarios estrictos, rituales debidamente controlados, de eventos culturales a prácticas deportivas. Mejor dicho, se trata de un cooper permanente...

En este punto podría recurrir a abundante material brasileño. Pero confiando en la imaginación de los presentes y en la lógica cultural que obliga a ver el Mismo en el Otro, paso enseguida a la conclusión. Son ejemplos que se repiten por el mundo, donde las administraciones locales sólo están interesadas en crear imágenes prestigiosas, a pesar de que ya nadie tiene la ilusión de que ocurra algo significativo, social o culturalmente. A nivel virtual permanecemos a pesar de todo como si la ciudad, en fin, el mundo (la realidad sin rodeos) se hubiese evaporado a golpes de estilización hiperrealista, eclipsándose en una avalancha de imágenes. De hecho, tales estrategias de ges-

11. Marc Augé, Não-lugares. Introdução à uma antropologia da supermodernidade, São Paulo: Papirus ed., 1994.

12. Postmodernism or Cultural Logic of Late Capitalism, Duke University Press, 1991; caps. 1 y 4. tión no pasan, la mayoría de las veces, de "estrategias aseguradoras", que colocan este mundo simulado en el lugar del de la más calamitosa desagregación social que el desarrollo del capitalismo — del crecimiento sin empleo...está generando. De representaciones de valores locales, de teatros de la memoria, como pretendían los arquitectos empeñados en la resemantización de la ciudad, poco sobró en estos escenarios que en realidad obedecen a una lógica de la evocación que funciona más como una antimemoria colectiva.

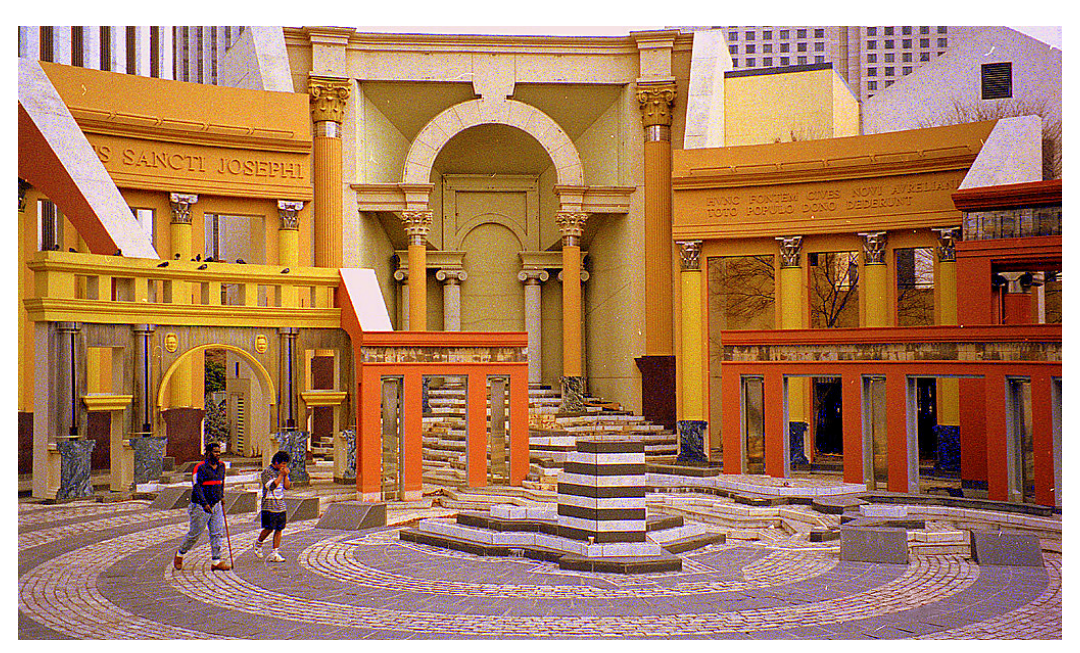

Piazza d'Italia, New Orleans (Charles Morre) 1978

En suma, la preservación y restauración de muchos monumentos pasados, en especial la "limpieza" de los viejos centros urbanos con sus edificios públicos no hacen, en general, más que esconder las marcas del tiempo $\mathrm{y}$, reprimiendo sus metamorfosis, provocar la reducción de todo a lo idéntico, una especie de "orden blanco de la 
memoria" (en la expresión de Jean Pierre Jeudy) ${ }^{\mathbf{1 3}}$ — autonomía autorreferida y fluctuante de los significantes, definitivamente cortados de toda realidad. Pero aquí ya pasamos a cuestiones que extrapolan el ámbito de nuestra exposición. Me refiero al problema más amplio de la gestión de la cultura y la correspondiente estetización de la memoria, del cual la creación de espacios públicos, reducidos a meros objetos destinados a ser devorados por el mirar, es apenas un aspecto, tal vez el más evidente, dados los alegatos ideológicos a que se presta para justificar las grandes intervenciones, o mejor dicho, las grandes inversiones. 


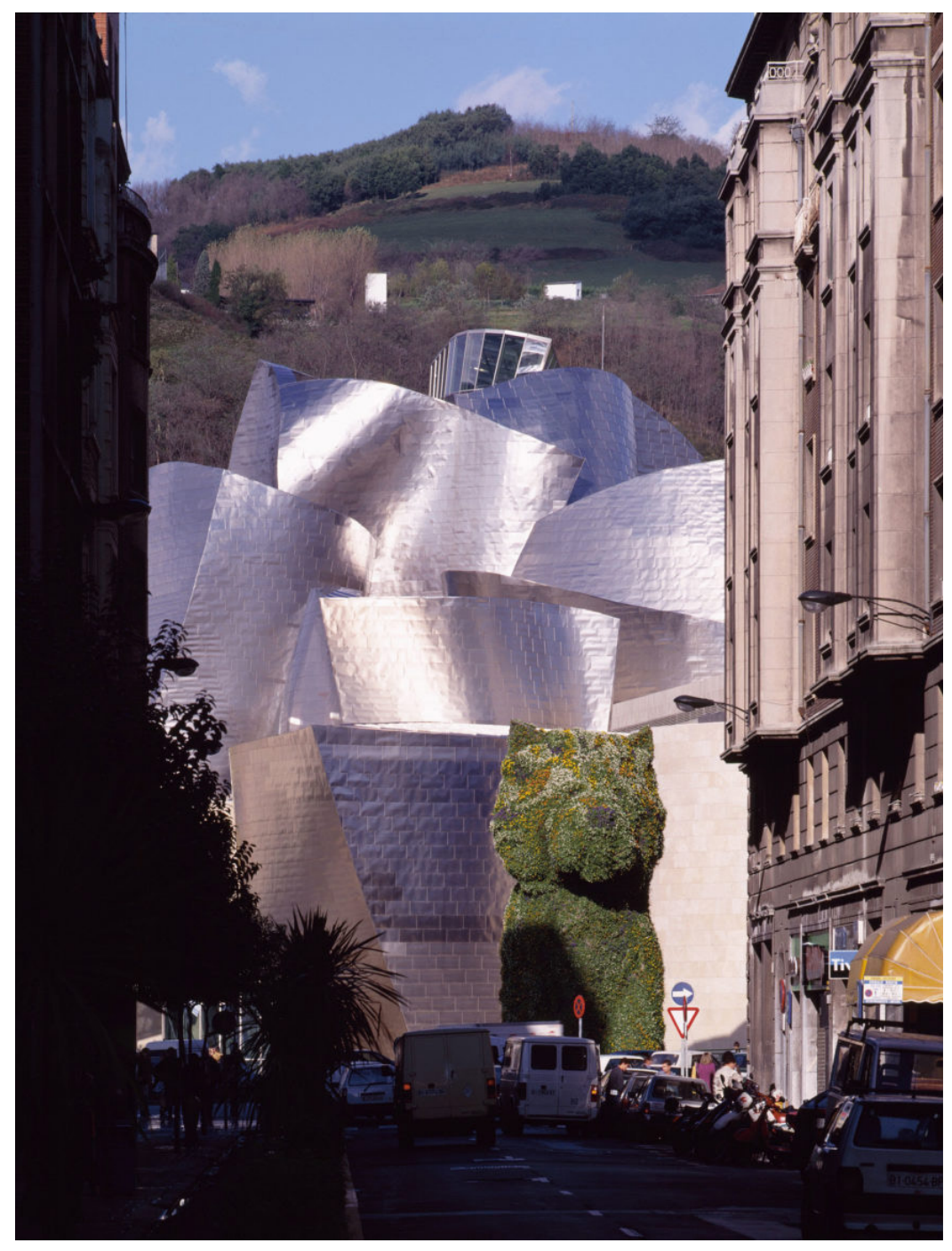

Frank Gehry, Museu Guggenheim, Bilbao, 1997

\section{Pasen y veán... Imagen y city-marketing en las nuevas estrategias urbanas*}

Hace algunos años, Bilbao era apenas una entre un sinnúmero de ciudades asoladas por el flagelo de la globalización, es decir, una más de las ciudades degradadas por una década de desindustrialización. En su jerga tan particular, un arquitecto-urbanista de última generación empeñado en reconstruir el sentido perdido de la ciudad, diría que una ciudad como Bilbao estaba en el punto óptimo de la crisis, carente de un plano de renovación urbana -que llamará estratégico- capaz de generar respuestas competitivas a los desafíos de la globalización. Y más: como se trata también de una sensación colectiva aunque subjetiva de crisis, responsable incluso por una baja dramática en la autoestima de sus habitantes, el abordaje recomendado en esta circunstancia debería revestirse de un carácter sobre todo simbólico, propio de los emprendimientos de comunicación y promoción. Sería por lo tanto aconsejable que el ancla de la operación urbana fuese de naturaleza identitaria, motorizada de preferencia por un proyecto de animación cultural.

Así se hizo. Después de alguna polémica, la municipalidad se dejó convencer de que al final había llegado la

* Publicado en la revista Punto de Vista $n^{\circ}$ 66, Buenos Aires, abril de 2000, pp.16-19, traducción de Adrián Gorelik del articulo "Vendo Cidades", en Veredas, $\mathrm{n}^{\mathrm{a}} 36$, Rio de Janeiro: CCB, diciembre de 1988, pp. 21-23. 
ocasión de dotar a la ciudad de un monumento con características tales que permitiese identificar a la capital vasca del mismo modo en que, por ejemplo, el edificio del teatro de ópera identifica a Sidney. El resultado es bien conocido, un museo de la Fundación Guggenheim, proyectado por el arquitecto norteamericano Frank Gehry, una extravagante flor metálica de cien millones de dólares emergiendo del río Nervio, destinada a multiplicar la oferta cultural de la ciudad, como se dice en la lengua franca del momento. En cuanto a la reversión del proceso de deterioro urbano, es un tema aparte que aun no ha sido evaluado.

Más allá de esto, querría destacar otro aspecto de esa negociación de la que resultará la nueva imagen de la ciudad. ¿Qué es lo que ella anuncia? En primer lugar, que la ciudad tiene un Gehry, así como San Francisco tiene un museo firmado por Mario Botta, Los Ángeles un Isosaki, más un Richard Meier, etc., todos miembros del star system de la arquitectura mundial. Esa imagen estratégica está informando, por lo tanto, que existe de ahora en más en el País Vasco una real voluntad de inserción en las redes globales, que su capital dejó de ser una ciudad-problema y puede convertirse en una confiable ciudad-negocio. De hecho, lo que se pone a la vista es el propio emblema de la credibilidad, las señales emitidas por aquel consumado ejemplar de manierismo arquitectónico: materiales ostensiblemente calculados para ofuscar por el brillo high tech; atmósfera de vanguardia sugerida por los volúmenes de corte deconstruccionista; ambiente introvertido de un enclave para los happy few. Un icono, en fin, del mundo de los integrados, en este caso la indispensable ventana de los altos servicios culturales abriéndose hacia el terciario avanzado, sin el cual la mencionada voluntad elegantemente arribista de inserción no pasaría de un ruego piadoso.
Identificación paradojal, como mínimo. Porque el reconocimiento externo e interno buscado se daría en torno de un punto de fuga, tanto más aglutinador local, como se pretende, cuanto más se presenta como una verdadera marca de extraterritorialidad, implantable de modo indiferente en cualquier otro nodo de la malla global. Por eso mismo se llama simbólica a esa identidad estratégicamente planificada con los medios de alta persuasión de la cultura arquitectónica de la imagen, aumentada por dos décadas de posmodernismo. En cuanto al relleno del museo, quedará en gran parte por cuenta de las colecciones itinerantes del propio Guggenheim: suceso en red, cuya resonancia cultural local tampoco es relevante, o mejor, se limita a colas interminables de gente, doble imagen de concurrencia que confirma el acierto de la inversión en los servicios de alta visibilidad, de preferencia de escala monumental. Frente a una sonda cultural como esta, una agencia internacional de evaluación de riesgo concluiría que en el País Vasco los gobernantes finalmente resolvieron "pensar global para hacer local", como manda la buena gramática gerencial.

Todo comenzó en Barcelona. No estoy queriendo sugerir que se trata de una invención ibérica, sino sólo recordar que con el tiempo la planificación de Barcelona —llamada después estratégica- se fue convirtiendo en un paradigma dentro de lo que se convino en llamar urbanística de tercera generación. La de primera generación comenzó a ser mal vista alrededor de los años cincuenta, por culpa de las intervenciones drásticas de tipo tabula rasa que se realizaban en nombre de una visión funcional de la ciu- 
dad-máquina de la era industrial. Fue abandonada en seguida por una urbanización sin modelos fijos, que alegaba modestia en sus intervenciones por lo general puntuales, respetuosa de las culturas locales. No pasó mucho tiempo, de todos modos, para que esa política urbana, centrada en la ideología multicolorida de la diferencia, revelara su fragilidad estetizando guetos y reforzando la fragmentación urbana; de suerte que, buscando dominar las nuevas patologías urbanas de la ciudad en la era llamada posmoderna, se fue cristalizando un nuevo ciclo de gestión urbana: proyectos de ciudad definidos por un plano estratégico que abarca un poco de todo, desde las gentrificaciones habituales en los casos de rehabilitación urbana por medio de la atracción especulativa de inversores y habitantes solventes (el eufemismo dice todo acerca de quienes salieron de escena), hasta las exortaciones cívicas dirigidas a los llamados actores urbanos, que de recalcitrantes se volverían cada vez más cooperativos en torno de los objetivos comunes de city marketing. Porque es de eso de lo que se trata. Sin más rodeos: desarrollar una imagen fuerte y positiva de la ciudad; como vimos, todavía incipiente aunque elocuente en la discípula Bilbao. Es que el modelo se generalizó, se convirtió en fórmula de exportación para las municipalidades interesadas en tornarse competitivas mediante el refuerzo de la imagen, en los términos planteados.

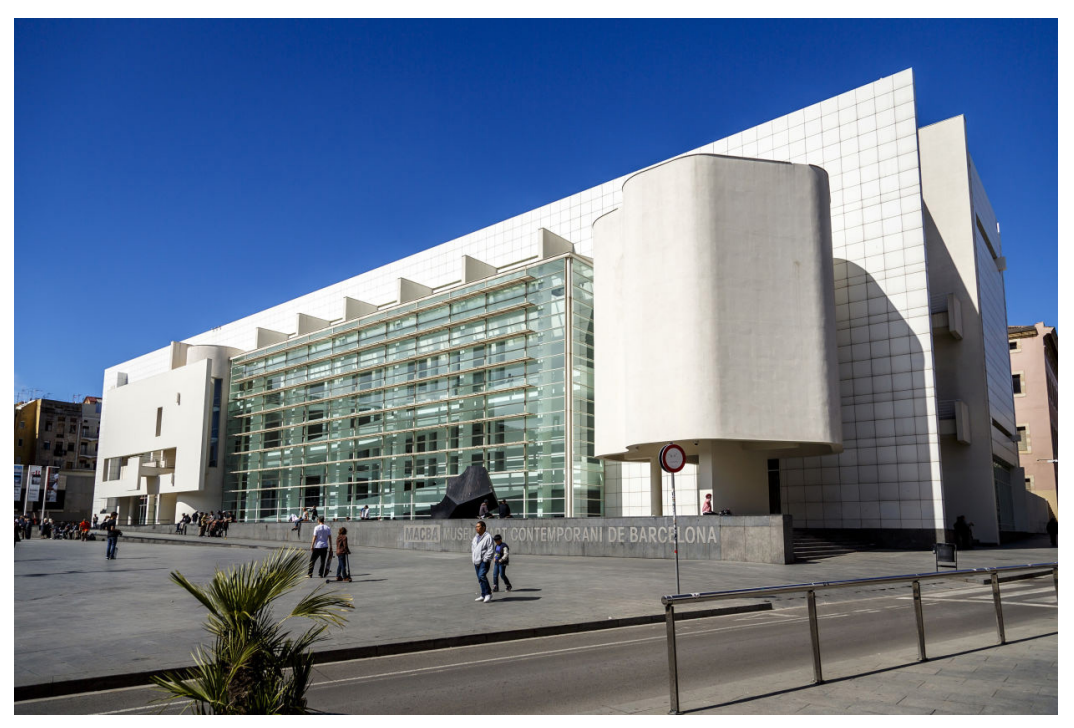

Richard Meyer, MACBA, Barcelona, 1995

Barcelona innovó también en otro requisito importante de esa estrategia de image making y consecuente reconversión empresarial de las ciudades. Me refiero, todavía en jerga, a una respuesta competitiva específica, como es el aprovechamiento estratégico de un megaevento internacional, en este caso la Olimpíada del 92, sin la cual la fórmula Barcelona seguramente no se habría convertido en la actual vitrina del admirable mundo nuevo de la globalización. Así como en los ejemplos anteriores Frank Gehry, Botta, Meyer y Cía. Son intercambiables o se pueden superponer de cualquier modo - cuanto más piezas en el muestrario, mejor-, ¿será preciso agregar que la naturaleza de tales eventos no viene al caso siempre que, por supuesto, sean de escala mega o global? Como observó un estudioso de esas ciudades, a las que bautizó de ocasionales, tanto sea la Copa del mundo, Exposición de esto o aquello, o incluso una catástrofe natural, lo único que importa es saber que millones de personas o 
metros cúbicos de tierra serán removidos. Mientras implique dispendios y remuneraciones adecuadas, daría lo mismo abrir y cerrar agujeros de dimensiones faraónicas, es decir, pirámides y otros prismas espectrales en los que se cristaliza la imagen mítica del rentable bienestar en la ultramodernidad. Como el capitalismo también es una máquina de generar insignificancia - aunque las cifras de sus emprendimientos no lo sean-, destinada a acumular indefinidamente más de lo mismo, no hay paradoja, sino involuntaria coherencia, en un proyecto de restauración del sentido original de "hacer ciudad" (como se dice en los prospectos) al servicio de "ocasiones" sin significado urbano intrínseco, más allá de la equivalencia general de las buenas oportunidades, indiferentes en sí mismas mientras abran una puerta para la globalización - puerta estrecha por definición.

No todos los planos de recualificación de las ciudades aspirantes a protagonistas globales son derivados del paradigma Barcelona. Lejos de eso. Pero alcanza con que se trate de promoción mediante comunicación de imagen para que todos tengan el mismo aire de familia.

Véase el caso obvio de la Expo 98 de Lisboa. En principio otro megaevento planeado para servir de embrión de la reconversión urbana de una vasta zona industrial y portuaria de Lisboa. Por lo demás, el terreno ya había sido allanado a lo largo de 1994, cuando la ciudad disfrutaba de la condición oficial de capital cultural europea, con derecho a todas las promociones que se desprenden de allí. ¿Pero qué se expone en Lisboa? En el plano de los reflejos automáticos - resorte secreto en el negocio de imáge- nes-, cuando se habla de Portugal se piensa (?) en Grandes Navegaciones y Descubrimientos. Dicho y hecho: la Expo 98 fue en verdad un inmenso parque temático, algo así como un híper-acuario conmemorativo de la expansión ultramarina del proto-capitalismo europeo. Y siendo así se presenta en la forma de un catálogo arquitectónico vivo del star system de siempre, aunque hábilmente condimentado con una fuerte representación de los talentos locales. Por lo tanto, nada se expone más allá de la propia exposición, como corresponde a la naturaleza tautológica de un proceso eternamente concentrado en la autocontemplación celebrativa. En cuanto a la imagen-identidad de la capital en promoción, será tanto más eficaz cuanto se limite a anunciar que, al final, Portugal es Portugal.

Algo semejante pasa en Berlín en la actualidad. Como se puede leer en un artículo reciente del fidedigno Vargas Llosa, la antigua capital del Reich se va transformando "en la mayor empresa (sic) arquitectónica y urbanística de la que se tiene memoria", a lo que agrega que para elevar la ciudad al status simbólico de capital de la Unión Monetaria Europea, "la niña de los ojos de tal promoción (sic) fue la cultura". Y, confirmando que lo que se cultiva en la imagen promocional de una ciudad es ella misma, la próxima Bienal de Berlín anuncia como tema la propia Berlín, de modo que el visitante no pierda de vista que lo que está en juego es la nueva capital a la búsqueda de su... identidad. Tan vacía e incontestable como la certeza de que A es igual a A. 


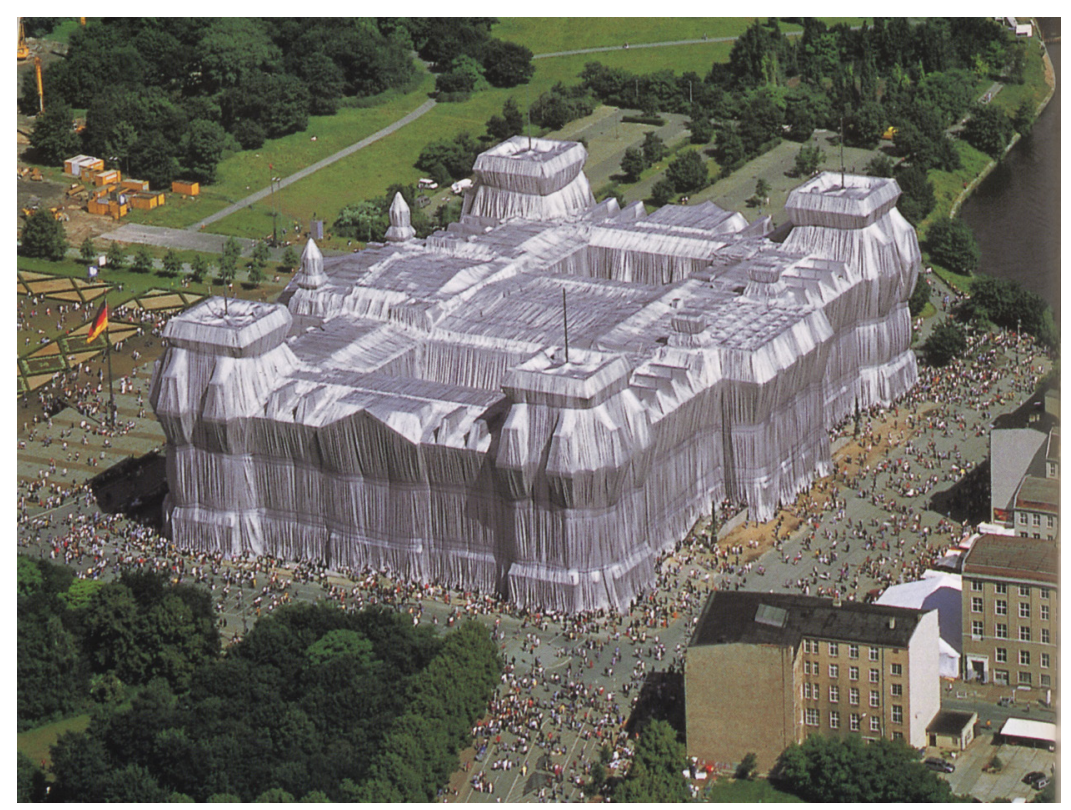

Christo e Jeanne-Claude, 'Embalaje' del Reichstag, antes de su recuperación, 1995

Dos diagnósticos de época que, a primera vista, parecen incompatibles, disputan atualmente la preferencia de las opiniones, a primera vista dos juicios incompatibles: para el primero, en el mundo de hoy todo es cultural; para el segundo, no hay nada que escape a la determinación económica, no en última, sino en primerísima instancia. Así, la realidad, que es una sola, se ve ya como enteramente cultural, ya como puramente económica. Sin excluir la hipótesis de que todo es cultural por razones económicas y viceversa.

De ahí ese curioso entrecruzamiento: por un lado, urbanistas y arquitectos de ascendencia las más de las veces progresista, proyectando en términos gerenciales provo- cativamente explícitos. Por otro, el espectáculo surrealista de empresarios y banqueros enalteciendo el "pulsar de cada calle, plaza o fragmento urbano". Como se trata de una armoniosa pareja estratégica, terminaron todos hablando la misma jerga de autenticidad urbana, que se podría denominar culturalismo de mercado. Invirtiendo y proyectando de acuerdo. Ya se inventó la empresa-ciudadana, un animal de zoología fantástica engordado a excepciones de todo tipo. Es natural que él críe a su imagen y semejanza una ciudad-empresa, con cortes de gastos, expulsión de personal superfluo y clientes identificados con la cultura de la firma. 

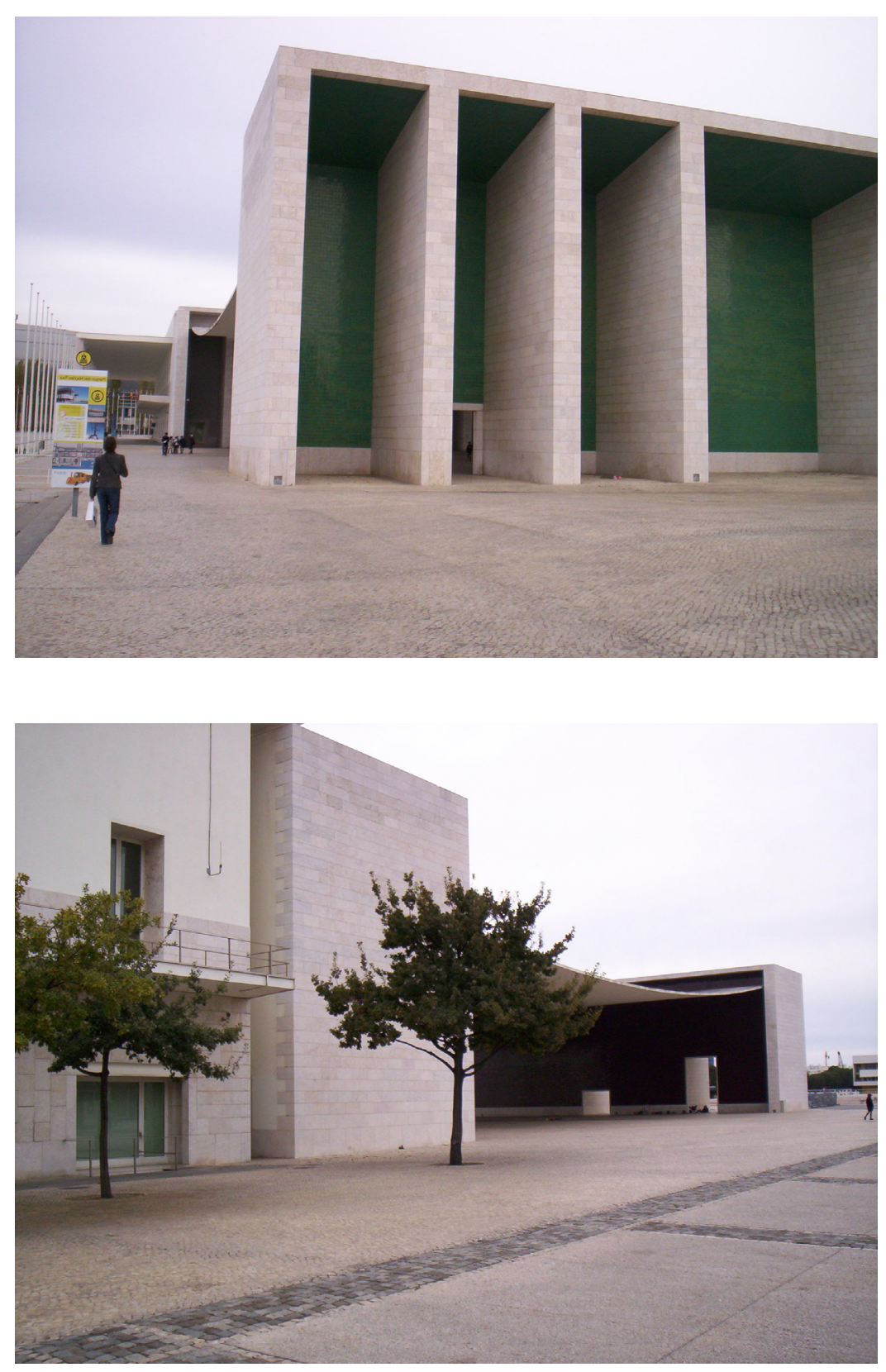

Álvaro Siza, Pabellón de Portugal en la Expo 1998

\section{Cultura y coaliciones de poder y dinero en las nuevas gestiones urbanas*}

A pesar de que la Feria de Hannover frustró las expectativas respecto del público que debería atraer un acontecimiento de esa magnitud con toda su parafernalia, o de que iniciativas como el Duomo del Milenio hayan resultado un fracaso, sin contar la última Copa del Mundo -que llevó a la quiebra a varias ciudades francesas-; o aun cuando, molestos, los franceses protesten con razón por la rueda gigante que cortó el eje que se extendía de la Cour Carrée y de la Pirámide al Arco de La Défense, pasando por el Arco del Triunfo, y que vociferen contra la inflación de centros culturales en el momento de decidir sobre el uso de la antigua fábrica de Renault en la isla de Séguin; aun así los gobernantes y gestores urbanos parecen confiar en la fórmula mágica de los grandes eventos, con sus megaproyectos, para atraer turistas e inversionistas hacia sus respectivas ciudades. Sucesos como el de las Olimpíadas en Barcelona, el de los Grandes Proyectos Parisinos, especialmente en la década de 1980, o incluso el del exuberante Museo de Bilbao (que finalmente elevó a Ghery al cielo del star system, y logró, al mismo tiempo, que este reflotara su proyecto para Disney Hall Center en Los Ángeles y

* Este texto es una reelaboración, especial para la revista Block ( $n^{\circ}$ 5, Buenos Aires, UTDT, diciembre de 2000), del ensayo "Estrategia fatal", en Arantes, Vainer y Maricato, A cidade do pensamento único. Desmanchando consensos, Petrópolis, Vozes, 2000. Traducción de Ada Solari. 
fuese convocado para otros cinco museos en los Estados Unidos, entre ellos el nuevo Guggenheim de Nueva York), parecen ofrecer la receta de una fórmula mágica de "hacer" ciudades (como se lee en los prospectos).

No hace mucho tiempo hice la siguiente observación, especialmente en relación con la Expo 98 de Lisboa: ya sea que se trate de Olimpíadas, la Copa del Mundo, la Exposición de tal o cual cosa, una catástrofe natural, 200 años de la revolución francesa, 500 años del descubrimiento de América o del Brasil, o incluso de un show-case como un museo extravagante, lo único que importa es saber que serán movilizados millones de personas y de metros cúbicos $^{1}$. Siempre que implique dispendios y remuneraciones considerables, es lo mismo que se abran y cierren agujeros de dimensiones faraónicas, o que se construyan pirámides u otros prismas espectrales en los que se cristaliza la imagen mítica del rentable bienestar en la ultramodernidad. Como el capitalismo es también una máquina de producir insignificancia -aunque las cifras de sus emprendimientos no lo sean-, destinada a acumular indefinidamente más de lo mismo, no hay paradoja, sino más bien involuntaria coherencia, en un proyecto de restauración del sentido original de "hacer ciudad" al servicio de “ocasiones" sin significado urbano intrínseco, más allá de la equivalencia general de las buenas oportunidades, indiferentes en sí mismas mientras abran una puerta para la globalización -puerta estrecha por definición-. Ese es, sin dudas, uno de los rasgos del urbanismo llamado de última generación: se vive al acecho de ocasiones... ipara hacer

1. Cfr. "Pasen y vean... Imagen y city marketing en las nuevas estrategias urbanas", Punto de Vista N ${ }^{\circ} 66$, abril de 2000. [Reproducido en esto e-book]. Allí tomé una expresión de Francesco Indovina: "ciudades-ocasionales". negocios! Y lo que está a la venta es un producto inédito: la propia ciudad, que para ello debe adoptar una agresiva política de marketing. Como lo indica la misma terminología habitual, estamos frente a políticas de image-making, es decir, business-oriented, aun cuando se argumenta (incluso de buena fe) que se trata de dar visibilidad a personas o colectividades que desean de hecho esa promoción. Porque, en efecto, uno de los ingredientes de la nueva fórmula, en las palabras de dos de los más famosos ideólogos del urbanismo llamado de última generación -esto es, de lo que se conoce como planificación estratégica-, es el “consenso público" o, todavía en el mismo plano eufemístico, la "voluntad conjunta", que forma la argamasa de esa construcción de ciudad y le permite dar "un salto hacia delante, tanto desde el punto de vista físico como económico, social y cultural"2.

Gobernantes, burócratas y urbanistas parecen converger en una especie de teorema-patrón: las ciudades sólo serán protagonistas, como les promete la Edad de la Información, si, y sólo si, son debidamente dotadas de un plan capaz de generar respuestas competitivas a los desafíos de la globalización, y esto ante cada oportunidad (siempre en el lenguaje de los negocios) de renovación que por ventura se presente bajo la forma de una posible ventaja comparativa para crear.

Si nos remitimos a la ciudad-máquina moderna, el cambio de los urbanistas no deja de ser espantoso: cuando los modernos proponían una ciudad según el modelo de la línea de montaje fordista, tenían en mente ante todo la supuesta racionalidad constructiva de ese proceso y se sentirían sinceramente ofendidos, como de hecho se sin-

2. Borja y Castells, Local y global, Madrid: Taurus, 1997. 
tieron (dado que creyeron que se trataba de un desvío en la ruta), si se les planteara la dura verdad de su funcionalidad sistémica de origen, por así decirlo. Hoy, lo que podría haber sido motivo de escándalo -la revelación de la mercantilización integral de un valor de uso civilizatorio como la ciudad- se tornó una razón legitimadora invocada ostensivamente. El objetivo actual del urbanismo no es más el de corregir, sino el de incrementar la proliferación urbana, para optimizar la competitividad de las ciudades (todo el vocabulario es, por otra parte, claramente empresarial). Cambiamos la máquina de habitar moderna por esta máquina de crecimiento, $y$, como se verá a continuación, no soy yo quien lo dice.

Retrocediendo en el tiempo, megustaría hacer una recapitulación de las grandes intervenciones urbanas que están en el origen de ese proceso: nada más y nada menos que las ciudades-empresas americanas que surgieron en los años setenta, según la clasificación de Peter Hall en Ciudades del mañana, publicado en 1988. Además, la naturalidad con que algunos urbanistas tratan el empuje empresarial provocado por el triunfo indiscutible del mercado, lleva a que el fenómeno que nos ocupa se revele sin disfraces. Es el caso de Peter Hall, cuya percepción desprejuiciada nos interesa en más de un aspecto. Hall da a entender que la ciudad-empresa habría nacido de las cenizas del consenso keynesiano, por una especie de cambio repentino desconcertante, en rigor, sin mediaciones ni mayores consideraciones: "Hubo un momento en la década de 1970 en el que la planificación urbana se puso cabeza abajo [...] La utilización de planos y reglamentos para guiar el uso del suelo parecían cada vez más desprestigiados. En su lugar, la planificación dejó de controlar el crecimiento urbano y paso a alentarlo por todos los medios posibles e imaginables. Las ciudades -el nuevo mensaje sonó en alta vozeran máquinas de producir riquezas; el primer y principal objetivo de la planificación debía ser aceitar la máquina. El planificador se fue confundiendo cada vez más con su tradicional adversario, el promotor; el guardabosque se transformaba en cazador furtivo"3. Dado que el autor no puede ser sospechado de mayores simpatías hacia la izquierda, su testimonio es inigualable.

No cabe recapitular aquí en detalle los hechos que marcaron en la década del setenta la gran reversión de los treinta años de expansión de la posguerra, sin los cuales la quiebra de la economía urbana y el colapso subsiguiente de las ciudades serían incomprensibles. Sin embargo, cualquiera sea el esquema explicativo del largo descenso de la economía mundial, el hecho es que con el fin de la Era del Crecimiento la planificación urbana, destinada por definición a disciplinarlo, perdió su carácter de evidencia y cifra de la racionalidad moderna, y se tornó el blanco predilecto de la ofensiva liberal-conservadora políticamente victoriosa desde 1979/1980. Pero faltaba la fórmula salvadora que diese cuerpo a tamaña obsesión con el crecimiento, justificado obviamente por la creencia economicista en el efecto trickle down de la expansión de la actividad.

3. Cidades do amanhã, São Paulo, Perspectiva, 1995, p. 407. [El original en inglés es de 1988, y hay traducción española de 1996: Las ciudades del mañana, Barcelona: Ediciones del Serbal. Nota del traductor] 


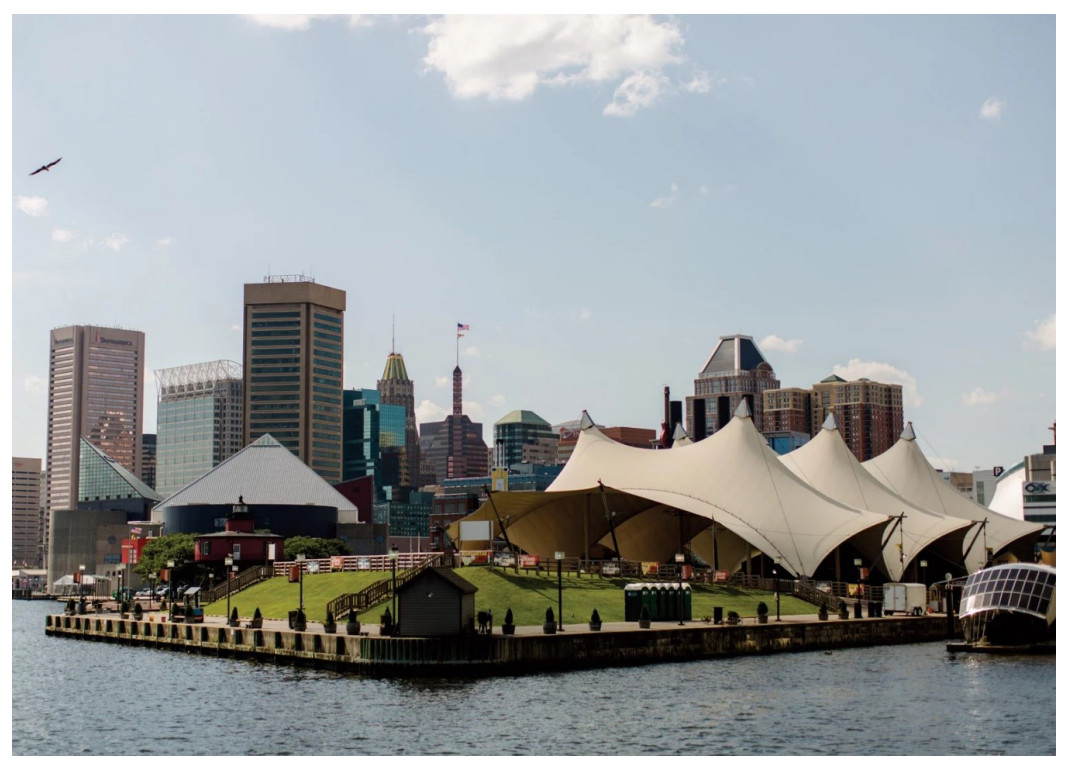

Harbor Place, Baltimore (renovación 1958-1965)

Para variar, la receta vino de los Estados Unidos. Y con ella, otra palabra señuelo, la célebre "revitalización urbana", así como sus no menos célebres derivados: la asociación entre sector público e iniciativa privada, encargada a su vez de "palanquear" (otro neologismo yanqui: to levarage) inversiones privadas con fondos públicos (siempre según la descripción de Peter Hall). El autor recuerda que el agente clave, el catalizador de este cambio, fue el empresario de Baltimore, James Rouse. La "rousificación" de América puede ser apreciada por la multiplicación de las réplicas de "recualificaciones" (otra palabra mágica de la época) desde el Inner Harbor de Baltimore y los esquemas equivalentes del Boston Waterfront y del Quincy Market, también en Boston, por ejemplo, hasta el Fisherman's Wharf de San Francisco, y así de seguido. Según la apreciación -evidentemente, crítica- de David Harvey: se trata de fenómenos indisociables de la condición posmo- derna ${ }^{4}$. El derrotero que este último adopta es en el fondo el de la periodización del "espectáculo urbano": la sustitución posmoderna del espectáculo como forma de resistencia o de fiesta popular por el espectáculo como forma de control social.

Veamos. En los años sesenta, la escena de las ciudades americanas fue invadida por manifestaciones por los derechos civiles, movilizaciones contra la guerra en el sudeste asiático y motines de todo tipo, sobre todo en los barrios negros, ya que buena parte del descontento urbano, no hay que olvidarlo, giraba en torno de los proyectos "modernos" de habitación y renovación de los equipamientos funcionales típicos, ahora amenazados por disturbios que se tornaban endémicos. Pero en el inicio de los años setenta, toda esa movilización terminó siendo "capturada por fuerzas bien diferentes y empleada para fines bien distintos". Baltimore se tornó entonces un instructivo resumen de esta evolución del espectáculo urbano. Y aquí está el punto que quisiera destacar: la espectacularización bien conocida de Harbor Place (para no hablar de eventos característicos como la Feria de Baltimore, un notable suceso según los interesados) terminó concentrando el juicio en la dimensión más disfrutable de la nueva receta -“la arquitectura del espectáculo, con su sensación de brillo superficial y de placer participativo efímero, de exhibición, de transitoriedad y jouissance", etc.-. No sin razón, por cierto, y no sólo por la estetización bastarda sino, antes, por el impacto nulo sobre la pobreza y demás déficits sociales. De ese modo se soslayó el contenido de la

4. David Harvey, A condição pós-moderna, São Paulo, Loyola, 1992, pp. 88-92 [edición en ingles de 1990 y hay traducción en castellano: La condición de la posmodernidad, Buenos Aires: Amorrortu, 1998, Nota del traductor.] 
iniciativa que, siguiendo a Harvey, es necesario recordar de forma breve pero precisa: neutralizar, entre otras cosas, los efectos del asesinato de Martin Luther King en 1968, que amenazaban la viabilidad de las inversiones, lo que llevó a los líderes locales a buscar un símbolo en torno del cual construir una idea de "ciudad como comunidad" en oposición a la ciudad sitiada, como veía el ciudadano común al centro de la ciudad y sus espacios públicos. Así surgió la Baltimore City Fair como forma de promover el redesenvolvimiento urbano, celebrando la buena "vecindad" y la diversidad étnica de la ciudad; el paso siguiente dio lugar a la "comercialización institucionalizada de un espectáculo más o menos permanente en la construcción de Harbor Place", que recuerda que los propios grupos étnicos comenzaron a lucrar con "la venta de etnicidad", a falta de mercado para su fuerza de trabajo. Hasta aquí -para retomar nuestro derrotero-, Harvey y el mapa general de la condición posmoderna, igualmente destacada por Peter Hall, pero con el agregado de la observación de que esta creación deliberada de un escenario cuyo prototipo había sido la "rousificación" de Boston y Baltimore (en el límite, la comprensión de la intervención urbana como un proceso de producción de lugares de éxito), era el registro y la garantía espectacular de que -en las palabras del autor- "una nueva y radical elite financiera tomaba evidentemente posesión de la ciudad, liderando una coalición pro crecimiento que manipuló hábilmente el apoyo público y combinó fondos federales y privados para promover una urbanización comercial en gran escala"5.

5. Peter Hall, op. cit., p. 413.
En pocas palabras, la idea de ciudad como growth machine (utilizo aquí una expresión puesta en circulación en los Estados Unidos por Molotch en 1976, de la cual la ciudad-empresa de Hall es apenas una variante) ${ }^{6}$ puede ser resumida del siguiente modo: coaliciones de elite centradas en la propiedad inmobiliaria y sus derivados, más una legión de profesionales dependientes de un amplio arco de negocios derivados de las posibilidades económicas de los lugares, configuran las políticas urbanas a medida que dan libre curso a su propósito de expandir la economía local y aumentar la riqueza. La fabricación de consensos en torno del crecimiento a cualquier precio -que es la esencia de toda localización- se torna la pieza clave de una situación de movilización competitiva permanente en la batalla de suma cero con las ciudades competidoras. Se trata, por lo tanto, de una fábrica por excelencia de ideologías: del territorio, de la comunidad, del civismo, etc. Y en el corazón de esas coaliciones está la clase rentista de siempre, hoy nuevamente a la vanguardia de los "movimientos urbanos": emprendedores inmobiliarios, intermediarios, banqueros, etc., amparados por un séquito de coadyuvantes igualmente interesados y poderosos, como medios masivos, políticos, universidades, empresas deportivas, cámaras de comercio y, finalmente, nuestros dos personajes en este enredo de estrategias: planificadores urbanos y promotores culturales.

6. "La ciudad como máquina de crecimiento", publicado por primera vez en 1976 en el American Journal of Sociology. Poco más de un año antes de la publicación de Las ciudades del mañana, la comunicación de Molotch había sido retomada extensamente en un libro en coautoría con John Logan, Urban fortunes: The political economy of place, University California Press, 1987. Véase también Jonas y Wilson (comps.), The urban growth machine. Critical perspectives two decades later, New York: State University of New York Press, 1999. 
Con el restablecimiento de la hegemonía americana, vulgarmente conocida como "globalización", el modelo máquina-de-crecimiento se generalizó con el pretexto de responder a las mismas presiones competitivas en torno del capital escaso y nómade, pero en verdad para responder a los imperativos (políticos) de la cultura anglosajona de los negocios ${ }^{7}$, al punto de convertir en un dato natural la convicción de que las ciudades deben ser dirigidas no "like business", sino "for business" (todavía de acuerdo a Molotch). O, por otra parte, todo sucede como si la transnacionalización productiva y financiera, al contrario de lo que sería previsible, en función del acentuado localismo de las máquinas urbanas de crecimiento, terminase otorgando -justamente debido a la reorientación de los estados nacionales, cada vez más vaciados socialmente y más deslegitimados, en la vía de una simbiosis aún más estrecha con el mundo de los negocios que deben ser pública y premeditadamente "palanqueados"- una segunda juventud cosmopolita a las parroquiales coaliciones urbanas pro-crecimiento.

Finalmente, no se trata de comprobar la colonización de la animación cultural (que, por otra parte, nació colonizada, como lo indica su mismo nombre) por la ciudad como "máquina de crecimiento", sino sobre todo de la operación inversa: el nuevo combustible sin el cual la coalición no fabrica los consensos necesarios. A pesar de que el foco de los análisis de Molotch es el conjunto de condiciones para poner en movimiento la máquina urbana de "aumentar rentas agregadas" y no exactamente la cultura, ya indica como ingredientes indispensables en

7. Cf. John Gray, Falso amanhecer: os equívocos do capitalismo global, Rio de Janeiro: Record, 1999. los buenos negocios (quién diría, con cuánta antelación) el "orgullo cívico" de los habitantes del lugar y el "patriotismo de masas", retomados, literalmente, en el recetario presentado como "planificación estratégica" en el Habitat II por Borja y Castells ${ }^{8}$. La diferencia es que lo que los teóricos (apologistas o críticos) de la ciudad-empresa veían como una convergencia rentable, los "estrategas catalanes" pretenden que sea una "articulación" concertada..., y por consiguiente capaz de inducir una nueva ola de civilidad, agregando ambigüedad al malentendido entre política real y epidermis cultural.

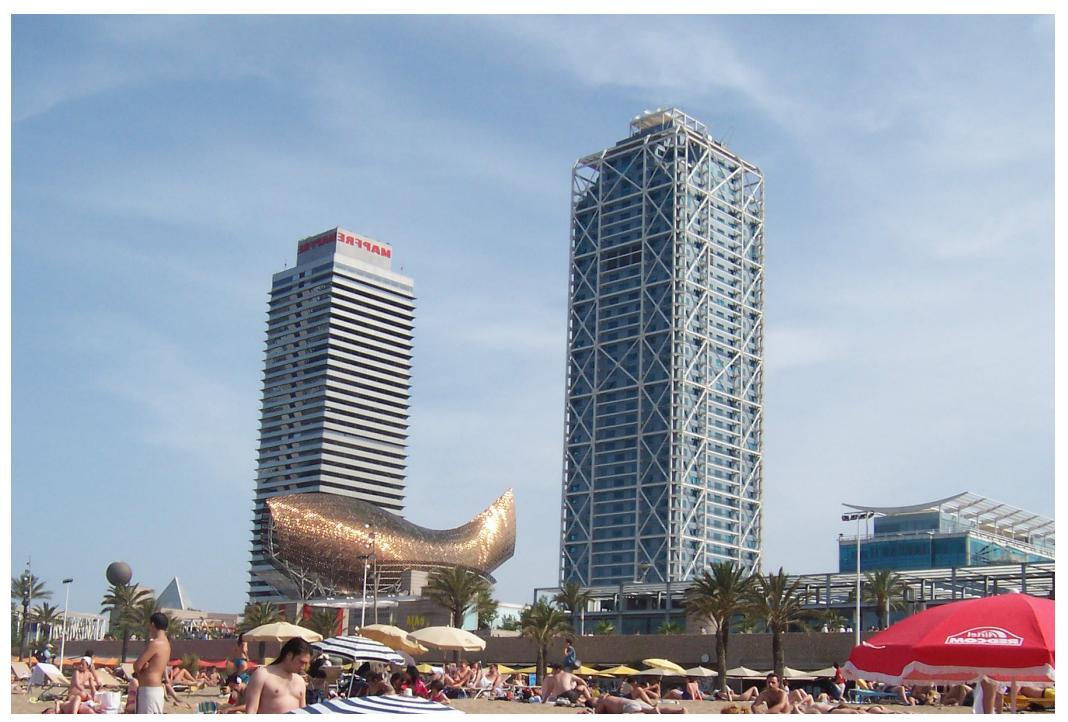

Hotel Arts (con escultura en forma de pez de F. Gehry) y Torre MAPFRE, frente al puerto Olímpico de Barcelona, construido por ocasión de la Olimpiada de 1982

8. Op. cit., cap. 5. 
En verdad, la máquina urbana de crecimiento no es nada más que una máquina ideológica accionada por los que administran la construcción tanto física como imaginaria de los recursos capaces de impulsar el desarrollo dentro y a través de los "lugares" de la ciudad, denominados de forma apropiada urban imagineers. En estas circunstancias, no resulta extraño que el arquitecto-urbanista se haya convertido en uno de los operadores claves de esta máquina, reuniendo en un sólo personaje al manager (el planificador-emprendedor identificado por Peter Hall) y al "intermediario cultural" (cuya existencia Bourdieu fue el primero en señalar; una fracción de clase que ofrece bienes y servicios y cuya trayectoria ascendente es reveladora del actual culturalismo del mercado). Intermediario y empresario cultural, al mismo tiempo que uno de los principales agentes de la gentrificación. El vocablo original inglés, gentry, deja descaradamente al descubierto el carácter de clase de este término: de allí la sombra de mala conciencia que suele acompañar su uso avergonzado, y por esa razón se lo escamotea con eufemismos como revitalización, rehabilitación, revalorización, reciclaje, promoción, recualificación, o incluso renacimiento, y así de seguido, encubriendo mal, por el contrario, el sentido original de invasión y reconquista, inherente al retorno de las camadas ricas al corazón de las ciudades.

Lo que quiero sugerir es que la planificación llamada estratégica puede no ser más que otro eufemismo de gentrificación, aunque no sean exactamente lo mismo -quién sabe sino será, tal vez, su apoteosis: una ciudad estratégicamente planificada de la $\mathrm{A}$ a la $\mathrm{Z}$ no sería otra cosa, finalmente, que una ciudad enteramente gentrificada-. Por ello, abriré un paréntesis (con algunos ejemplos) acerca de este tópico, que se volvió uno de los puntos de honra de la dilución culturalista del despojo urbano, pues finalmente lo que interesa siempre es determinar quién sale y quién entra, sólo que ahora se trata de una apropiación del espacio legitimada por el upgrading cultural.

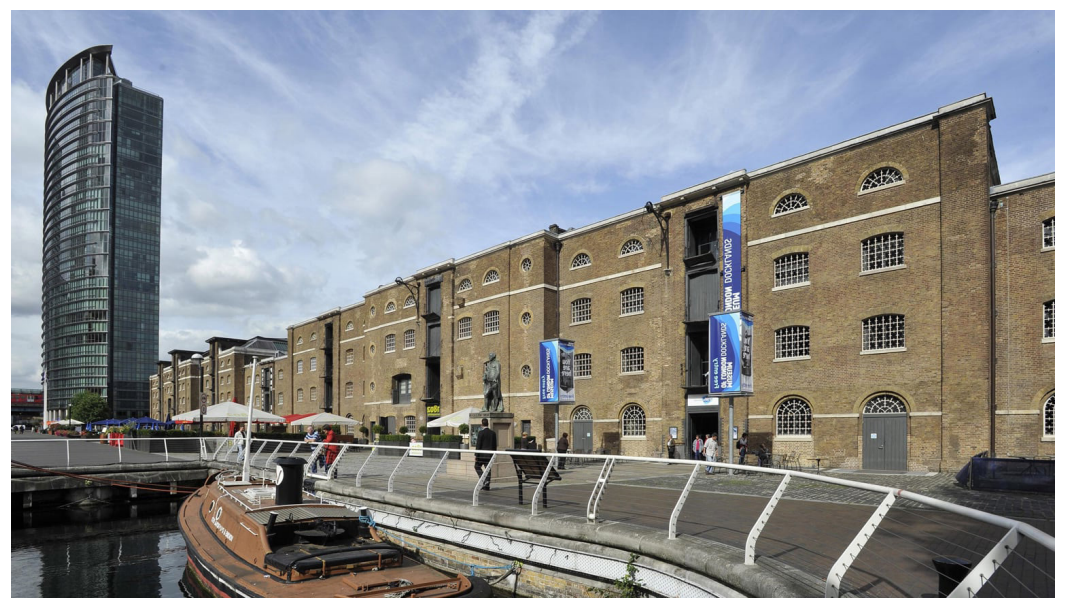

Museo de la ciudad de Londres, en la Docklands gentrificada

No por acaso, el modelo más conocido y repetido de esta asociación hegemónica entre especuladores, políticos y urban imagineers se encuentra en Nueva York, en el proceso de gentrificación del SoHo, inicialmente por medio del incentivo al reciclaje de los lofts por la comunidad local de artistas, que fue la novedad en la articulación de capital y cultura en la remodelación de la ciudad, novedad destacada por el estudio pionero de Sharon Zukin ${ }^{9}$. Para

9. Loft Living. Brunswick, Rutgers University Press, 1989 (la primera edición es de 1982). David Harvey le dio los debidos créditos al prologar la edición británica de 1988. Véase también de Harvey otro comentario sobre el tema en: Condição pós-moderna, op. cit., p. 82. 
variar -o mejor, por primera vez de modo ejemplar, a partir de los años setenta-, se rehabilitaba el área arruinada por medio de una operación "concertada" (como dirán los ideólogos catalanes) de recualificación de los espacios desactivados de las viejas fábricas, convertidos en galerías o incluso en residencias de artistas, boutiques, restaurantes considerados sofisticados, etc., y por consiguiente la migración forzada de los antiguos habitantes y la reconversión de los pocos propietarios remanentes en intermediarios de altos negocios inmobiliarios. Nuevos patrones de gusto y consumo difundían la sensación reconfortante de que una vida de artista, esta vez reconciliada con la sociedad, podía ser el atributo de una nueva vanguardia de la burguesía -todo movido, por cierto, gracias a transgresiones sistemáticas de la legislación con la mal disfrazada aquiescencia de la administración local-.

Allí se encuentra el embrión de un cambio emblemático: a medida que la cultura pasaba a ser el principal negocio de las ciudades en vías de gentrificación, se hacía cada vez más evidente para los agentes envueltos en la operación que era ella, la cultura, uno de los más poderosos medios de control urbano en el momento actual de reestructuración de la dominación mundial. Como se puede leer en un estudio posterior de Zukin acerca de las estrategias culturales del nuevo desarrollo urbano, cuya médula reside nuevamente en la propagación de la imagen de un centro de innovación, cualquiera sea, de los servicios financieros a la seguridad máxima de los públicos solventes ${ }^{\mathbf{1 0}}$ : es necesario distinguir por encima de la base formada por los factores económicos clásicos sobre los cuales se edifica una ciudad -tierra, trabajo y capital-al menos tres cama-

10. Culture of Cities, Cambridge: Blackwell, 1985, cap. 1. das de intercambios desiguales y, además, "simbólicos". La primera es la manipulación de lenguajes simbólicos de exclusión y habilitación (entitlement): lo "visual" de una ciudad, así como la manera en que se deja, por así decir, tocar con la mano, su aspecto "táctil", reflejan decisiones sobre qué y quién puede estar visible o no, decisiones en suma sobre orden y desorden, lo que conlleva algo así como una estetización del poder, en la que el diseño arquitectónico es uno de los instrumentos más aparatosos. En la segunda camada, nos encontramos de nuevo con la máquina de Molotch: es que la economía simbólica de la ciudad también está dirigida por la habilidad de los "place entrepreneurs" (a quienes se sumaron hoy los últimos ideólogos del "lugar") para lidiar con los símbolos del crecimiento, y su promesa de empleos y negocios. Por último, el sector más tradicional, actualmente reactivado al ritmo de vorágine del capitalismo americano, la alianza entre los círculos de negocios y los "abogados de la ciudad" -esto es, la cobertura del multicolor edificio del Tercer Sector-, alianza que, por una combinación eficiente de mecenazgo y orgullo cívico, basado en el deseo de presentarse como un nuevo patriciado, se encargará de hacer multiplicar museos bombásticos, parques ídem y complejos arquitectónicos que aseguren a quien corresponda que se está entrando en una "world-class-city". Porque, en efecto, es esta simbiosis de imagen y producto ${ }^{11}$ lo que caracteriza a la ciudad-empresa-cultural perseguida por la actual generación urbanística.

No es el caso ahora de hacer un inventario de los innumerables ejemplos neoyorquinos de gentrificación estratégica, si es que se puede decir así, a pesar de que se trata de

11. Según la fórmula de Sharon Zukin, op. cit., p. 8. 
eso. El principio de la máquina cultural de crecimiento no varía demasiado, como se puede verificar en otra recualificación famosa, la de Battery Park, con el recorrido de siempre: concebido a mediados de los años sesenta como una nueva área habitacional en Manhattan, destinada en principio a diversas camadas sociales, se fue transformando poco a poco en un vasto proyecto de gentrificación impulsado por una sucesión de crisis (algunas forjadas) y medidas gubernamentales de "auxilio", con su habitual cortejo de comercio elegante y amenidades culturales, entre ellas un verdadero festival de arte público (o lo que actualmente se entiende así), en el que se consagraría la unión entre Arte y Urbanismo, debidamente enmarcada por una fantasía kitsch, según la cual el encuentro de tierra y agua que allí se celebraba descendía de la misma noble estirpe de Venecia, Constantinopla y San Petersburgo ${ }^{12}$.

La última novedad: se gentrifica Harlem, con la demolición de varios edificios, especialmente de los distritos históricos de Hamilton Heighs y Sugar Hill. Es decir, nuevamente, lo obvio: en nombre de una memoria reactivada y de una identidad reconquistada, no cabe preguntar por la suerte de los actuales habitantes que seguramente no podrán sostener los costos de alquiler, cuando departamentos de dos ambientes pasen a costar U\$S 2.000 por mes.

Con estos pocos casos, no obstante ejemplares, habría ahora que completar el razonamiento y señalar algo aparentemente trivial, pero que en verdad hace tiempo dejó de serlo: el hecho de que las áreas gentrificadas son áreas altamente vigiladas. Este último aspecto es el módulo más sencillo del mecanismo de subordinación de un espa-

12. Cf. Rosalyn Deutsche, Evictions, Cambridge: MIT, 1996, pp. 79-93. cio público al control privado, para variar, en la forma de alguna ONG creada ad hoc por la coalición local de rehabilitadores urbanos: se rediseña el lugar; se programan acontecimientos culturales, se abre un café o algo similar que resulte igualmente chic, y se completa el servicio con una pequeña horda de vigilantes. $\mathrm{Y}$ así se continúa, con intervenciones cada vez más complejas, hasta cubrir quizá toda la ciudad que importa, su enclave verdaderamente global. Llegamos finalmente a lo que ya fue llamado "estetización del miedo"13 y que es en verdad el incentivo secreto del repentino interés de las elites globales por el espacio público, acerca del cual comenzaron sintomáticamente a hablar profusamente: no hay mecenas que se precie que no patrocine alguna área pública, con el celo ancestral demandado por esa nueva moda de enclosures, como en los tiempos de la acumulación primitiva.

A esta altura vale la pena no perder de vista el origen militar de la palabra estrategia, que fue trasplantada de la esfera semántica de la guerra económica, con involuntaria precisión, a un urbanismo que al menos confiesa necesitar adversarios, por otra parte fácilmente identificables. De este modo, pienso que hay que incluir en la "ciudad revanchista" descripta por Neil Smith la gentrificación estratégica de la que hablamos. ${ }^{14}$ La designación no debe sorprender en una era de revancha del capital en todos los frentes, cuya magnitud se explica por el Gran Miedo que siguió a la explosión de los años 1960/1970. En la arena urbana, revancha contra los trabajadores precarizados, los inmigrantes, los sin techo, en fin, todo tipo de clase

13. Por la misma Sharon Zukin en el libro citado.

14. The New Urban Frontier, Londres: Routledge, 1996. 
peligrosa capaz de amenazar el sueño de los vencedores de ayer. Por ciudad revanchista Neil Smith entiende más específicamente la vuelta agresiva de las gentrificaciones después de las grandes quiebras de los años ochenta, pero sobre todo como reacción ante el deterioro urbano provocado por la primera ola de desregulaciones y recortes en los programas sociales. No es difícil percibir, además, que el revanchismo que anima sin disfraces la expresión de una escalada más extensa y profunda en la guerra social contemporánea, cristalizada, entre otras enfermedades de la actual hegemonía global, en una especie de nuevo sentido común penal -criminalización de la pobreza y normalización del trabajo precario-, cuya manifestación urbana también puede identificarse en una suerte de principio de inviolabilidad del espacio público, por eso mismo sometido a una estricta vigilancia privada ${ }^{15}$. Una "nueva doxa punitiva" alimenta la progresiva sustitución del Estado social por el Estado penal (5\% de la población americana masculina adulta está bajo vigilancia penal, y de ella, el $80 \%$ está formado por negros), tanto como la estetización cultural del miedo inducida por la fase actual de gentrificación. Ahora bien, otra ironía, esta vez semántica, pero en sintonía con los vaciamientos que estamos viendo, consiste en bautizar con el nombre de civilidad nada puede tener mayor énfasis cultural- al avance punitivo que celebra cada movimiento de profundización del nuevo Estado penal como un gesto de audacia cívica contra el debilitamiento de la voluntad política de los gobernantes. No hay dispositivo de seguridad que no represente entonces alguna fuerza civilizatoria. Como la "tolerancia

15. CF. Loïe Wacqant, «Ce vent punitif qui vient d'Amérique», Le Monde Diplomatique, abril de 1999. cero" del alcalde Giuliani, para dar el ejemplo más común: así, según el actual administrador de Nueva York, "en una ciudad civilizada, las calles no son un lugar para dormir, las personas deben usar cuartos".

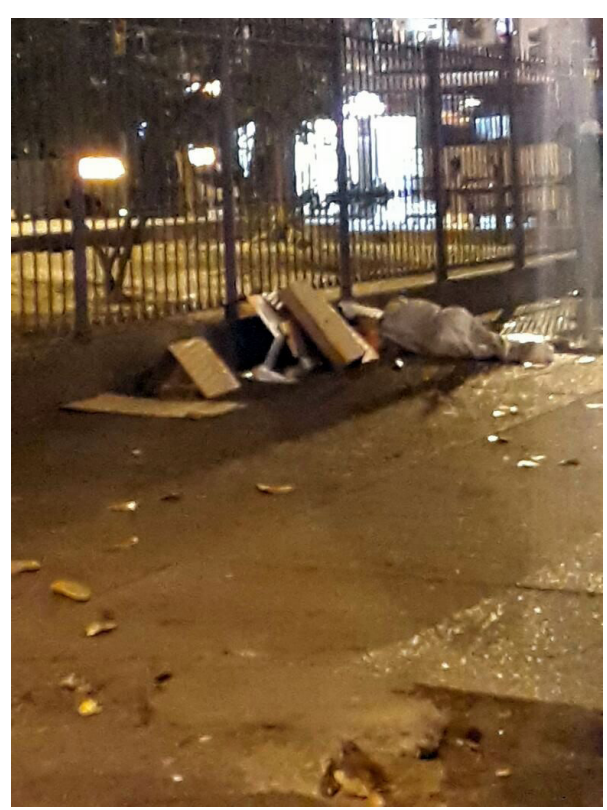

Rejilla de protección y ¡miedo! Rio de Janeiro

No sorprende que en esas circunstancias la jerga de la civilidad haya impregnado el montaje de las nuevas estrategias urbanas; finalmente, ambos tienen el mismo origen en el management empresarial. Y por el patrón Giuliani de civilidad podemos imaginar lo que sucede hoy dentro de una empresa-ciudadana. Y, por extensión, en los espacios gentrificados de una ciudad-empresa-cultural, que debería describirse nuevamente desde otro ángulo: no solo como ciudad-negocio, sino también como una ciudad civilizada en todos sus engranajes -desde una ven- 
dedora de boutique hasta un transeúnte benévolo como si se viviese en una ONG asfaltada-, como una sola empresa regida por un único script de atención al cliente, como en cualquier local de fast-food. En las ciudades globales causa por cierto la mejor de las impresiones, otra razón más para replicar el modelo en los enclaves de la periferia.

Por esas y otras consideraciones, cuando se habla hoy, a diestra y siniestra, de "hacer ciudad", corresponde, ante tamaño eufemismo, hacer la pregunta: ¿quién de hecho "hace la ciudad"? La respuesta, al menos a partir de los años noventa, parece inequívoca: naturalmente, las grandes empresas, con las mediaciones de praxis, por cierto. Por eso, el mismo paisaje en todas partes, o mejor, sin contar los simulacros en la periferia, las mismas landscapes of power descritas por Sharon Zukin en ciudades globales como Nueva York y Londres ${ }^{\mathbf{1 6}}$. No hay nada que llame la atención en esto, ya que la recuperación de las áreas centrales en las dos ciudades cayó en las manos de las mismas instituciones financieras, de las mismas megainmobiliarias, de los mismos estudios del star system, que por su parte prepararon el terreno por encargo de las matrices multinacionales de siempre. Y así sucesivamente, van las grandes corporaciones multinacionales intentando persuadirnos de que los verdaderos protagonistas de la escena mundial son -quién lo diría- las ciudades, o mejor, ciudades cuya configuración sea propicia para la valorización patrimonial que más les interesa a estas firmas en

16. Lanscapes of power. From Detroit to Disney World, University of California Press, 1991. la etapa actual de transnacionalización productiva. Rentabilidad y patrimonio arquitectónico-cultural se dan la mano en este proceso de revalorización urbana-siempre, evidentemente, en nombre de un alegado civismo (¿cómo discutirlo?). Y para entrar en el universo de los negocios, la seña más prestigiosa -ia qué punto llegamos! ¿de sofisticación? - es la Cultura. Esa nueva marca del mundo fashion, de la sociedad de consumo de los altos servicios a la que todos aspiran.

Pero no cualquier cultura, este es el turning point que nos interesa señalar respecto de este último giro urbanístico: una cultura -desde la industria de la conciencia hasta las grandes fachadas, pasando por las gentrificaciones pertinentes- paradójicamente (¿o no?) respaldada por el aura libertaria de la resistencia antiproductiva cuya génesis se remontaría a los movimientos de los años sesenta. No tiene nada que ver con lo que se entendía por cultura en el ciclo histórico anterior, el breve interregno de la Era del Crecimiento de la segunda posguerra, para no hablar evidentemente de la vieja esfera autónoma y trascendente de la extinta Edad Liberal-burguesa.

Hubo así una metamorfosis de lo "cultural", cuyo posmaterialismo, al principio reactivo, se fue volviendo pro activo, para no decir cooperativo, a medida que se estetizaba y se concentraba en los valores expresivos de un orden social que argumentaba a su favor haber destronado la primacía de las relaciones de producción en nombre de las relaciones de "seducción", como fue celebrada la Era del Vacío en inicio. Si estoy en lo cierto, ni siquiera fue necesario esperar por las grandes desregulaciones del período siguiente, comenzando por la flexibilización de la rigidez fordista, para acelerar el cambio indoloro de lo libertario-cultural, empeñado en la recuperación de la 
riqueza simbólica de las formas urbanas (según el planteo de Leon Krier), en el embrión de los futuros propagadores de señuelos culturales para el capital -para quienes la monotonía funcional del modernismo había creado con certeza una fuerte demanda reprimida-.

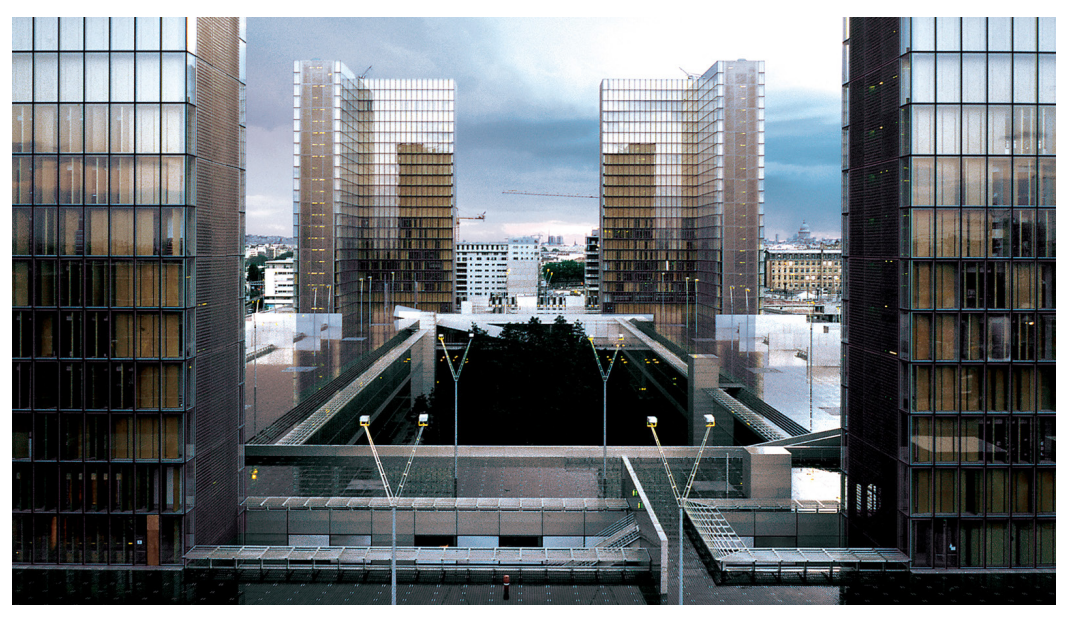

Dominique Perraul, La Biblioteca Nacional de Paris, 1989-1995

En verdad, aun cuando todo parece haber comenzado en los Estados Unidos, al cruzar el Atlántico, la máquina de crecimiento fue aceitada, especialmente en relación con el énfasis superlativo en la Cultura y con la convergencia seductora entre high culture y big business. De esta conjunción nacía el mito bifronte de la ciudad-collage-gran-proyecto, en la que la París de Mitterand será el máximo ejemplo y seguramente el punto de inflexión. Todo estaba allí, en las medidas de regulación flexible de lo urbano, desde la ampliación de la industria cultural que incorporaba la cultura de los museos y sus adyacencias highbrow al capitalismo de imágenes, el enaltecimiento arquitectónico del mundo de los negocios hasta la correspondiente mitología urbanizadora del terciario avanzado, sin la cual no se puede aspirar al status de ciudad global ${ }^{17}$.

Después de París, pasando por Barcelona hasta la nueva capital de la Alemania unificada, un sinnúmero de ciudades no hará más que aplicar la fórmula de la ciudad-empresa-cultural. Se trata, por así decirlo, de una composición del modelo liberal-americano y social-progresista europeo. En breve: sucedió lo que estamos viendo, algo así como un pensamiento único -en el que se unen el interés económico de la cultura y los alegatos culturales del comando económico-que ronda a las ciudades que compiten por el escaso financiamiento en el sistema mundial, y por eso mismo compartido a pesar de las preferencias político-ideológicas de los administradores de turno.

Me detengo en un último ejemplo, quizá el más significativo hoy: Berlín. Más allá de las diferencias, algo semejante ocurre actualmente en la nueva capital alemana. Por cierto, las proporciones son otras: superlativas. Al menos desde el punto de vista cuantitativo, no hay dudas de que nada en el mundo se equipara con la reconversión de Berlín "reconquistada". Fueron movilizados más de trescientos estudios de todo el mundo, en particular, obviamente, del star system: desde los complejos multifuncionales de la Postdamer Platz -Sony y Daimler Benz, bajo la dirección de Murphey/Jahn, Rogers/Piano y otros más, entre ellos algunos estudios alemanes, como especialmente el

17. Sobre esta cuestión, véase mi ensayo "Os dois lados da arquitetura francesa pós-Beaubourg”, en O lugar da arquitetura depois dos modernos, São Paulo: EDUSP, 1993, 1995, 2000. 
del arquitecto Kollhoff ${ }^{18}$-; hasta los museos, embajadas, estudios, grandes tiendas, edificios administrativos, y residencias por aquí y por allí. Todo proyectado para simbolizar no sólo a la Alemania unificada, con el patrocinio del Estado y de la municipalidad, sino también al mundo del capitalismo globalizado y triunfante (o, al menos, a la mayor potencia de la Unión Europea), transformando la antigua capital del Reich en el mayor show-room de la arquitectura de este fin de siglo (según algunos, menos entusiastas, un verdadero "baratillo") y en el símbolo más enfático del liderazgo alemán (por lo menos europeo). Como no podrían estar ausentes las antiguas tradiciones berlinesas, se reconstruyen los viejos edificios de la Pariser Platz, se mantiene el diseño urbano y, en la medida de lo posible, se restringen las regulaciones. Extraña combinación de osadía y autoritarismo, en una reforma que, a pesar de todo, ha sido criticada como ¡extremadamente conservadora! Irritado, Rogers se quejó de que era imposible proyectar para Berlín algo que no fuese un edificio cuadrado, pero no por eso dejó de construir una caja-collage-muestrario de las soluciones adoptadas en otros proyectos suyos. (A pesar de la controversia de algunos arquitectos y empresarios con la administración, nadie quiere quedar afuera.)

En ese contexto, no se podría imaginar un lugar mejor desde donde observar la ciudad que, nada más y nada menos, la cúpula del Reichstag, entre las dos Berlín: un inmenso domo de vidrio sobre una estructura metálica proyectada por uno de los astros más celebrados de la arquitectura high tech (al fin de cuentas, Alemania es el frente de avanzada de la tecnología europea), Norman Foster (que es no obstante inglés...). En verdad, un híbrido más: la tradicional arquitectura neoclásica (de Wallot), que domina la ciudad desde Schinkel, combinada con la arquitectura de punta, internacional. Al mismo tiempo, hace converger el exterior y el interior del edificio, y el parlamento reunido detrás de las paredes del viejo edificio puede ser visto desde lo alto a través de un techo de vidrio. Transparencia de la democracia, ofrecida como espectáculo a los ojos del visitante embobado. Es significativo que la única área verticalizada - proyectada para ser el Manhattan de la Nueva Capital- sea justamente la región central de la antigua ciudad del este. Finalmente, el previsible cliché (nada mejor que la reiteración para vender): a medio camino entre el este y el oeste, Berlín repuesta en el epicentro de Europa, y, de acuerdo al subtexto, del mundo ${ }^{19}$.

18. Además, en Berlín algunos hablan del poder de la "mafia" de los arquitectos asociados a las empresas, al punto de haber aparecido ya en las noticias policiales. Sobre este tema, véase Eva Schweitzer, Grossbaustelle Berlin, wie die Haupstadt verplant Berlin, Berlin: Ullstein, 1998. Sobre arquitectura berlinesa, véase el catálogo Neue Architektur. New Architecture - Berlin 19902000, Berlín: Jovis, 1998.

19. Sobre esta cuestión, véase el artículo del senador para el Desarrollo, Peter Strieder, "Berlin, City of the futur?", Stadtforum, N 36, junio de 1999. 


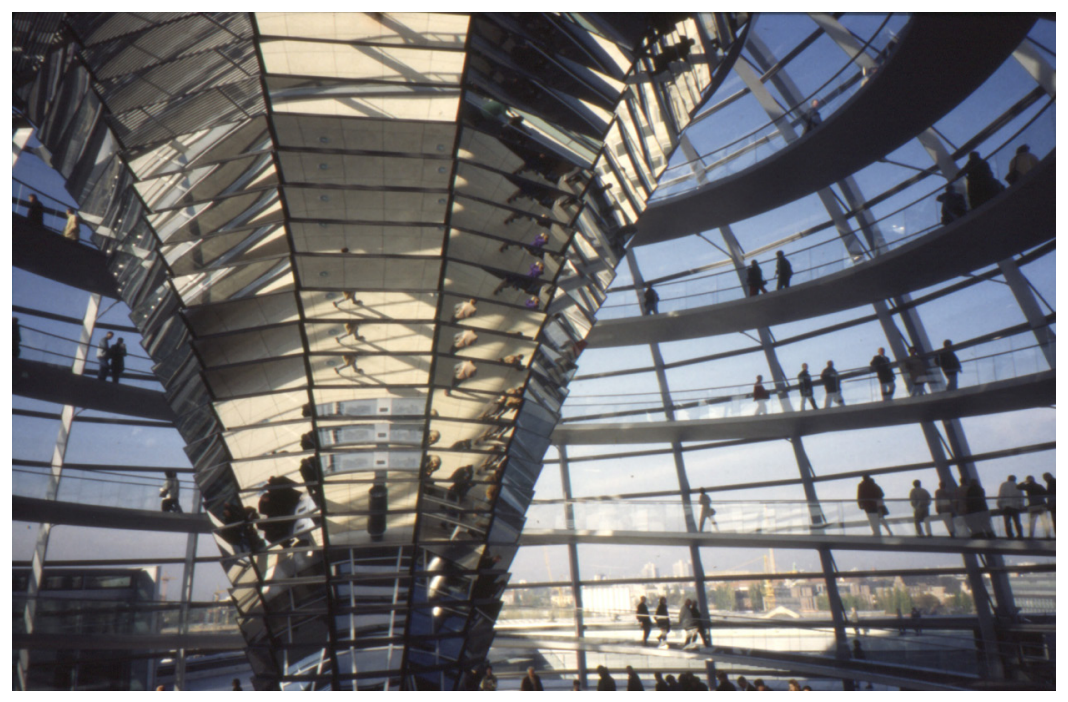

En el interior de la cúpula del Reichstag

Y en el foco de todo, la cultura ${ }^{20}$ : desde el patrimonio restaurado, especialmente la isla de los museos, al esfuerzo para reactivar los lugares más representativos de la Berlín de los estereotipados años veinte, como Postdamer Platz, Prenzlauer Berg, en el este, que vuelve a ser el barrio de la bohemia artística, o el viejo Mitte, resultado de la emigración de muchos jóvenes artistas, en especial los que vivían en viviendas ocupadas de Kreutzberg oeste, ahora elevados a la categoría de galeristas, estimulados por los subsidios del gobierno. Además, confirmando que el objeto de culto en la imagen promocional de una ciudad es la ciudad misma, la Bienal de Berlín, al renovarse com-

20. Como se puede leer en un artículo del insospechable Vargas Llosa, donde dice que la antigua capital del Reich se va transformando "en la mayor empresa [sic] arquitectónica y urbanística de la que se tiene memoria", e informa que para elevarla al status simbólico de capital de la Unión Monetaria Europea, "la niña mimada de esa promoción [sic] fue la cultura". "Cidade de todos", en: O Estado de São Paulo, 11/10/1998. pletamente, adoptó como tema a la propia Berlín (“Berlín/ Berlín") -de modo que el visitante no perdiese de vista que lo que está en juego es la nueva capital en búsqueda de su identidad (universal...). Tan hueca como el domo, e incontestable como la certeza de que $\mathrm{A}$ es igual a $\mathrm{A}^{21}$.

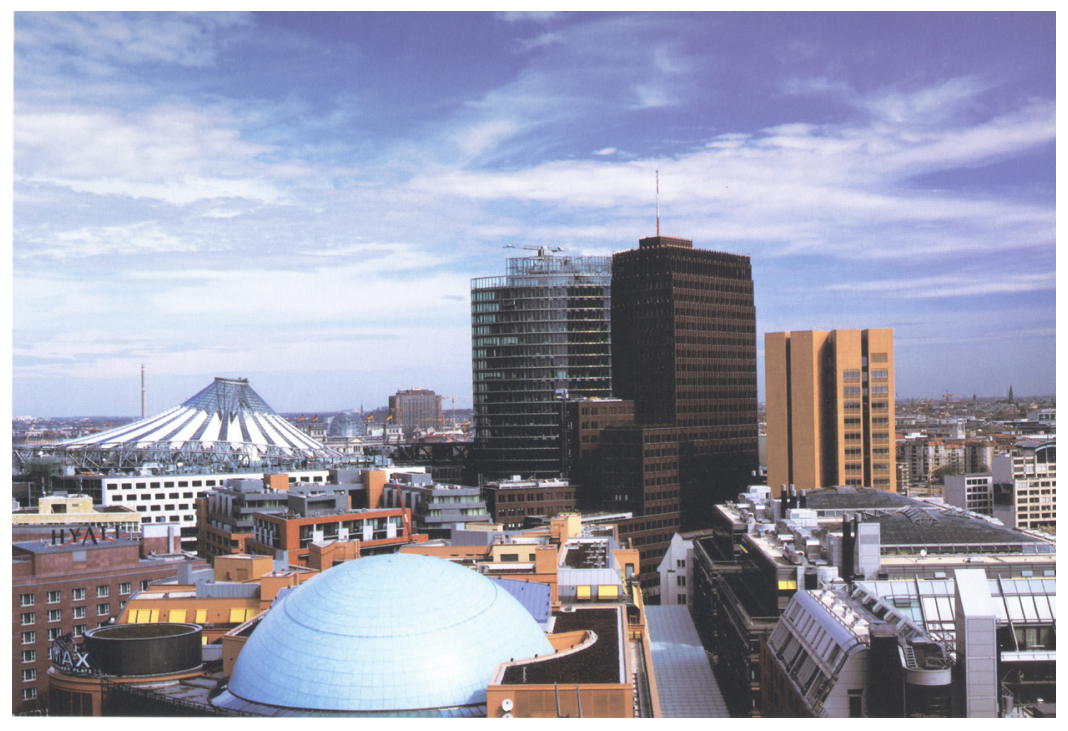

Vista aérea del conjunto de la Postdamer Platz, Berlin

Como en el caso de París, no hay en sentido estricto ningún Plan Estratégico por detrás de la renovación de Berlín. Y sin embargo la fórmula es la misma en todos los casos vistos hasta aquí, cualquiera sea el nombre de ocasión que se le dé. No falta ninguno de los ingredientes del actual modo de hacer ciudad, y en la escala gigantesca de una capital con ambiciones imperiales: megaproyectos emblemáticos; urbanismo premeditadamente corporativo (nin-

21. Para finalizar, retomo aquí una observación que ya hice en el artículo publicado en Punto de Vista $n^{\circ} 66$, citado. [Reproducido acá.] 
guna gran marca global está ausente); gentrificaciones esparciéndose por todos lados; exhibición arquitectónica en gran estilo; parques museográficos; salas de espectáculo agrupadas en complejos multiservice y mucha, mucha animación cultural las 24 horas. O sea, más de lo mismo.

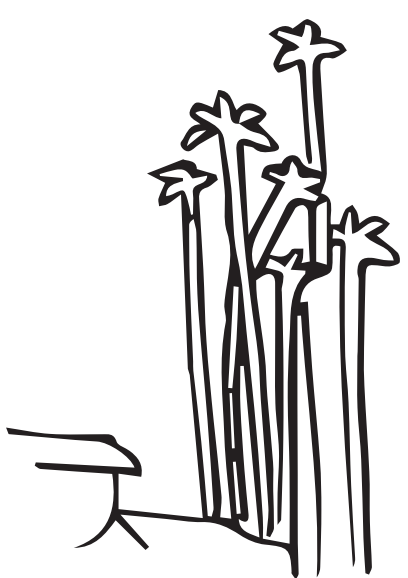

Este libro fue compuesto en fontes Literata e Work Sans en deciembre de 2021. 